\title{
Growth Temperature Regulation of Host-Specific Modifications of Rhizobial Lipo-Chitin Oligosaccharides: The Function of nodX Is Temperature Regulated
}

\author{
Maurien M. A. Olsthoorn, ${ }^{1}$ Ellen Stokvis, ${ }^{1}$ Johan Haverkamp, ${ }^{1}$ Herman P. Spaink, ${ }^{2}$ \\ and Jane E. Thomas-Oates ${ }^{1,3}$ \\ ${ }^{1}$ Department of Biomolecular Mass Spectrometry, Bijvoet Center for Biomolecular Research, Utrecht \\ University, Sorbonnelaan 16, 3584 CA Utrecht, The Netherlands; ${ }^{2}$ Institute of Molecular Plant Sciences, \\ Leiden University, Wassenaarseweg 64, 2333 AL Leiden, The Netherlands; ${ }^{3}$ Michael Barber Centre \\ for Mass Spectrometry, U.M.I.S.T., P.O. Box 88, Manchester M60 1QD, U.K. \\ Accepted 13 April 2000.
}

\begin{abstract}
Lipo-chitin oligosaccharides (LCOs) are usually produced and isolated for structural analysis from bacteria cultured under laboratory rather than field conditions. We have studied the influence of bacterial growth temperature on the LCO structures produced by different Rhizobium leguminosarum strains, using thin-layer chromatographic, high-performance liquid chromatographic, and mass spectrometric analyses. Wild-type $\boldsymbol{R}$. leguminosarum bv. viciae A1 was shown to produce larger relative amounts of $\operatorname{nod} X$ mediated, acetylated $\mathrm{LCOs}$ at $12^{\circ} \mathrm{C}$ than at $28^{\circ} \mathrm{C}$, indicating that the activity of $\operatorname{nodX}$ (a gene encoding an LCO $O$ acetyl transferase) is temperature dependent. Interestingly, symbiotic resistance genes sym1 and sym 2 found in primitive pea cultivars are also temperature sensitive, only being active at low temperatures, at which they block nodulation by $R$. leguminosarum bv. viciae strains lacking $\operatorname{nod} X$. We therefore propose that the gene-for-gene relationship between plant and bacterium has a temperaturesensitive mechanism as an adaptation to environmental conditions. An $R$. leguminosarum bv. trifolii strain was also shown to produce larger relative amounts of nodXmediated, acetylated LCOs at $12^{\circ} \mathrm{C}$ than at $28^{\circ} \mathrm{C}$. The major components synthesized by the two strains are produced at both temperatures but in different relative amounts, while some minor components are only produced at one of the two temperatures.
\end{abstract}

Additional keywords: fast atom bombardment, matrix-assisted laser desorption/ionization, nano-electrospray, Q-Tof.

The symbiosis between rhizobial bacteria and leguminous plants is a species-specific process that results in the formation of nitrogen-fixing root nodules. Successful nodulation results from a series of complex plant-microbe interactions

Corresponding author: Herman P. Spaink, Leiden University, Institute of Molecular Plant Sciences, Clusius Laboratory, Wassenaarseweg 64, 2333 AL Leiden, The Netherlands; Telephone: +31-71-5275055; Fax: +31-71-5275088; E-mail: Spaink@ rulbim.leidenuniv.nl that involve the production and mutual recognition of specific plant and microbial signal molecules. The plant signals are secreted flavonoids that induce the transcription of nodulation, or nod, genes in the bacterium. Many of these gene products are involved in the biosynthesis and secretion of lipo-chitin oligosaccharides (LCOs), or Nod factors, the signal molecules secreted by the bacterium. LCOs consist of an oligosaccharide backbone of two to six $\beta$-1 $\rightarrow$ 4-linked $N$-acetyl-D-glucosamine (GlcNAc) residues. A fatty acid group, the structure of which can vary from species to species, is attached to the nitrogen of the nonreducing-terminal residue. The structures of the LCOs are further elaborated by the addition of one or more of a range of different possible groups whose biosynthesis and/or transfer are mediated by the nod genes. The nodL gene, for example, encodes an $O$-acetyl transferase that specifically transfers an acetyl group to C-6 of the nonreducing-terminal residue (Downie 1989; Spaink et al. 1991), and nodX is involved in the addition of an acetyl group to C- 6 of the reducing-terminal GlcNAc residue of pentameric LCOs (Davis et al. 1988). The nature of the fatty acyl chain, the number of GlcNAc residues, and the combination of extra substituents, together determine the host specificity of the bacterium.

To date, three nodX-bearing Rhizobium leguminosarum biovars- $R$. leguminosarum bv. viciae TOM, R. leguminosarum bv. viciae A1, and $R$. leguminosarum bv. trifolii ANU843have been shown to produce nodX-mediated, acetylated LCOs. In addition to the GlcNAc ${ }_{5}$ LCOs bearing the specific $n o d X$-mediated acetyl group on the reducing terminal residue, these strains all produce LCOs bearing the nodL-mediated acetyl group on the nonreducing terminal residue. LCOs consisting of a GlcNAc backbone of four to five residues are produced by strain TOM and of three to five residues are produced by strain $\mathrm{A} 1$, and they carry as the major fatty acyl components $\mathrm{C}_{18: 1}$ and $\mathrm{C}_{18: 4}$ (Firmin et al. 1993; Ovtsyna et al. 1999). R. leguminosarum bv. trifolii ANU843, or derivatives of this strain, produce LCOs composed of three to five GlcNAc residues that bear a range of different fatty acids $\left(\mathrm{C}_{14-20}\right.$, with zero to four double bonds, and with or without a 
hydroxyl group) (Bloemberg et al. 1995; Orgambide et al. 1995; Philip-Hollingsworth et al. 1995).

Poor nodulation, which can lead to substantial loss of legume yield due to nitrogen deficiency, has been attributed to a range of environmental conditions, including unfavorable soil $\mathrm{pH}$, high salinity, drought, the presence of ions such as aluminum and nitrate, and deficiencies in essential elements including calcium and phosphorus (Bordeleau and Prévost 1994; Richardson et al. 1988; Sadowsky and Graham 1998; Trotman and Weaver 1995). Soil temperature is also an important environmental variable (Gibson 1971) that influences the growth and survival of rhizobia in the soil, their interaction with the legume host, and competition for nodulation. Low temperatures reduce nodule formation and nitrogen fixation in the rhizobial symbionts of temperate legumes; however, in the extreme environment of the high arctic, native legumes can be nodulated and the nodulating rhizobia can fix nitrogen at rates comparable to those observed in temperate climates, indicating that both plants and their rhizobia have successfully adapted to arctic conditions (Bordeleau and Prévost 1994; EkJandér and Fåhraeus 1971).

Most studies in which LCOs are produced and isolated for structural analysis are carried out with bacteria grown under laboratory rather than field conditions, typically with a growth temperature of $28^{\circ} \mathrm{C}$, at which the bacteria are considered to grow best. In the soil, however, bacteria grow and reproduce at much lower temperatures. To study the effects of growing bacteria at temperatures very different from those under which they naturally grow, we have analyzed the profile of LCOs produced, at a range of growth temperatures, by $R$. leguminosarum bv. viciae TOM (from Turkey), R. leguminosarum bv. viciae A1 (from northwest Russia), R. leguminosarum bv. trifolii ANU843 (from Australia), and R. leguminosarum bv. trifolii Troms $\varnothing$ 20-15 (from northern Norway), with thin-layer chromatographic (TLC) screening, and, for some of the strains, additionally with high-performance liquid chromatography (HPLC) and mass spectrometry.

In addition to the general reduction in nodulation at temperature extremes, there are also specific legume-Rhizobium spp. combinations that demonstrate temperature sensitivity. For example, R. leguminosarum bv. trifolii TA1 forms nodules on Trifolium subterraneum cv. Woogenellup in the laboratory at growth temperatures above $25^{\circ} \mathrm{C}$ but not below $22^{\circ} \mathrm{C}$, although it nodulates the majority of its host clover cultivars below $22^{\circ} \mathrm{C}$ (Lewis-Henderson and Djordjevic 1991a, 1991b). In the field, strain TA1 is renowned for its failure to nodulate cultivar Woogenellup (Gibson 1968). McKay and Djordjevic (1993) suggested that there might be a direct effect of environmental conditions on transcription, translation, or posttranslation events that affect the production and secretion of LCOs. Host-controlled restriction of nodulation has also been reported for primitive pea cultivars from the Middle East that are able to form nodules with most European $R$. leguminosarum bv. viciae strains at $26^{\circ} \mathrm{C}$ but not at $18^{\circ} \mathrm{C}$ (Kozik et al. 1995; Lie 1978). Resistance to nodulation by these strains at low temperatures is conferred by syml or sym2 (Lie 1984), recessive, allelic plant genes that are responsible for strainspecific nodulation behavior. $R$. leguminosarum bv. viciae strains able to overcome this resistance carry an additional gene, $\operatorname{nodX}$, first described in strain TOM (Davis et al. 1988). Introduction of this gene into European R. leguminosarum bv. viciae strains overcomes the resistance, indicating a gene-forgene relationship between syml or sym 2 and nodX. It has been proposed that sym 2 is involved in the early stages of the infection process controlling LCO-induced infection thread formation and that it encodes an LCO receptor or part thereof that specifically recognizes the nodX-modified LCOs (Firmin et al. 1993; Geurts 1998; Geurts et al. 1997; Kozik et al. 1995).

Kozik et al. (1995) suggested that pea lines from the Middle East carrying the resistance genes syml or sym 2 are temperature sensitive, since it is only at low temperatures that they block nodulation by $R$. leguminosarum bv. viciae strains lacking $\operatorname{nodX}$. In the present study, we have tested whether the bacteria also demonstrate temperature-sensitive regulation, i.e., whether the activity of $\operatorname{nodX}$ is also temperature dependent. The R. leguminosarum bv. viciae strains TOM and A1, both of which are able to nodulate Afghan pea, were induced with the plant flavonoid naringenin to produce LCOs at 6,12 , 18 , and $28^{\circ} \mathrm{C}$ to see whether, with TLC, there is a demonstrable difference in the relative amounts of nodX-mediated, acetylated LCOs produced at the different temperatures. Recently, it was shown that $\operatorname{nodX}$ from wild-type $R$. leguminosarum bv. trifolii ANU843 is very similar to the nodX genes from strains TOM and A1 (Ovtsyna et al. 1999). We have therefore additionally studied the influence of growth temperature after induction with naringenin on the LCO structures produced by two $R$. leguminosarum bv. trifolii ANU843 strains. The structures of the LCOs produced by strain A1 and one of the $R$. leguminosarum bv. trifolii ANU843 strains were identified following HPLC fractionation, with mass spectrometry.

\section{RESULTS}

\section{TLC analysis.}

Normal-phase TLC analysis with radioactive detection was carried out as an initial screen to study the influence of temperature on the resulting profile of LCO structures extracted from the bacteria. It was already known that reducing the growth temperature from 28 to $18^{\circ} \mathrm{C}$ resulted in an increase in the amount of radiolabeled LCOs produced by $R$. leguminosarum bv. trifolii (Spaink et al. 1995). Four nodXcontaining strains, wild-type $R$. leguminosarum bv. trifolii ANU843 ${ }^{\mathrm{RR}}, R$. leguminosarum bv. trifolii ANU843 ${ }^{\mathrm{RR}}$. pRI4003, wild-type $R$. leguminosarum bv. viciae A1, and wild-type $R$. leguminosarum bv. viciae TOM, were induced to produce LCOs at $6,12,18$, and $28^{\circ} \mathrm{C}$ (Fig. 1). Clearly, for all strains, LCO spot intensities at different growth temperatures are different. The TLC profiles for strains A1 and TOM are similar, with the most intense spots produced at $6^{\circ} \mathrm{C}$ and, in contrast, no radiolabeled and therefore observable spots at $28^{\circ} \mathrm{C}$. Strains ANU843 ${ }^{R R}$ and ANU843 ${ }^{R R}$.pRI4003 give LCO profiles with the most intense LCO spots obtained at 6 and $12^{\circ} \mathrm{C}$ and at 12 and $18^{\circ} \mathrm{C}$, respectively. The intensity ratios of the spots obtained at a particular temperature are different for these two strains, probably due to the fact that strain ANU843 ${ }^{\text {RR }}$.pRI4003 contains extra copies of its nod genes that may well result in the production of slightly different ratios of LCO structures. The absence of observable LCO spots from strains A1 and TOM on growth at $28^{\circ} \mathrm{C}$, the commonly used growth temperature, shows that it is advisable to induce 
uncharacterized strains to produce radiolabeled LCOs for TLC analysis at a range of different growth temperatures.

The chromatographic migration of LCOs from strain ANU $843^{\text {RR }}$ produced at $29^{\circ} \mathrm{C}$ has been published (Spaink et al. 1995b) and was used to identify the spots containing monoacetylated $\mathrm{GlcNAc}_{3}$, GlcNAc , and GlcNAc${ }_{5}$ LCOs (indicated with Roman numerals in Figure 1) in the profiles of the other strains. Surprisingly, at 6,12 , and $18^{\circ} \mathrm{C}$, in addition to spots of minor intensity, an extra spot is present in between the two major spots corresponding to monoacetylated $\mathrm{GlcNAc}_{4}$ and $\mathrm{GlcNAc}_{5}$ LCOs in the profile of strain ANU $843^{\text {RR }}$. Repetition of these experiments resulted in the same profiles showing this extra spot. Since the introduction of an acetyl group increases the hydrophobicity of an LCO and thus increases its $R_{\mathrm{f}}$ value on normal-phase TLC, this extra spot might correspond to pentameric LCOs bearing not only the nodL-mediated acetyl substituent but also a nodXmediated acetyl substituent. This extra spot was not detected in the TLC profiles (not shown) of LCOs obtained at different temperatures from a related $R$. leguminosarum strain, $R$. leguminosarum bv. viciae LPR5560 (Spaink et al. 1991), which does not contain nodX and which was used as a reference in the TLC experiments. From strain ANU843 $3^{\mathrm{RR}}$ grown at $6^{\circ} \mathrm{C}$, this extra spot seems to be at its relatively most intense when compared with the two major spots. Similarly for strain ANU843 ${ }^{\mathrm{RR}}$.pRI 4003 grown at $28^{\circ} \mathrm{C}$, this extra spot is weak in relation to the spots for the tetrameric and pentameric monoacetylated LCOs, while it is one of the major spots at the lower temperatures. In addition, this extra spot is the most intense spot produced at $6^{\circ} \mathrm{C}$ by strains $\mathrm{A} 1$ and TOM, while at $18^{\circ} \mathrm{C}$ it is the weakest spot produced by these two strains, indicating that for each strain the intensity of the extra spot, presumably corresponding to nodX-mediated, doubly acetylated, pentameric LCOs, relative to the monoacetylated GlcNAc $_{4}$ and $\mathrm{GlcNAc}_{5}$ LCO spots increases with decreasing growth temperature. However, only radiolabeled LCOs are visualized with TLC with radioactive detection and the growth temperature might influence the efficiency of uptake or incorporation of the radiolabel. We therefore fractionated the LCOs with HPLC with photodiode array detection and identified the LCOs obtained with mass spectrometry to obtain more detailed structural information on the range and relative amounts of LCOs produced at the different temperatures. The largescale isolation of LCOs was performed at 12 and $28^{\circ} \mathrm{C}$. Strain A1 was used because it produces much larger amounts of LCOs and a wider spectrum of different structures than does strain TOM (Firmin et al. 1993; Ovtsyna et al. 1999). In addition to the Australian wild-type R. leguminosarum bv. trifolii ANU843 ${ }^{\mathrm{RR}}$ and ANU843 ${ }^{\mathrm{RR}}$.pRI4003, wild-type $R$. leguminosarum bv. trifolii Troms $\varnothing$ 20-15 originating from the north of Norway was induced at 12 and $28^{\circ} \mathrm{C}$ for large-scale $\mathrm{LCO}$ production and isolation. The HPLC profiles obtained at the two different temperatures were compared in order to study the possible influence of the climatic origin of the bacteria on the amount of LCOs produced at high and low temperatures.

\section{HPLC analysis.}

The reverse-phase HPLC photodiode array profiles of the large-scale bacterial cultures of strains A1 (Fig. 2A,B), ANU843 ${ }^{R R}$.pRI4003 (Fig. 2C,D), ANU843 ${ }^{\text {RR }}$ (not shown), and Troms $\emptyset$ 20-15 (not shown) induced with naringenin to produce LCOs at 12 and $28^{\circ} \mathrm{C}$ show clear differences. The relative intensities of the HPLC peaks at the two temperatures are significantly different, indicating, as do the results of the TLC analysis, that the temperature affects the relative amounts of the different LCOs produced. Induction with naringenin of all strains except for ANU843 ${ }^{\mathrm{RR}}$.pRI4003 at the two temperatures was initiated in cultures having comparable $\mathrm{OD}_{620}$ values. Based on the absorption values at $206 \mathrm{~nm}$ for the different peaks in the HPLC profiles, strains A1 (from northwestern Russia) and Troms $\emptyset$ 20-15 (from northern Norway) seem to produce larger absolute amounts of LCOs at $12^{\circ} \mathrm{C}$ than at $28^{\circ} \mathrm{C}$, while the opposite holds for strain ANU $843^{\mathrm{RR}}$ (from Australia). In the case of the arctic strain $R$. leguminosarum bv. trifolii Troms $\varnothing 20-15$, it clearly seems to suggest that the best yield of LCOs is obtained at low growth temperatures, which are presumably closer to the natural soil temperature for this strain. Interestingly, incorporation of radiolabeled glucosamine is not necessarily most efficient at the temperature at which large amounts of LCOs are produced (see Figure 1), suggesting that incorporation of glucosamine into the LCOs is taking place in competition with normal 'household' glucosamine metabolism and stressing the desirability of carrying out radiolabeling experiments for initial screening with TLC analysis for uncharacterized strains at different temperatures. For example, the R. leguminosarum bv. trifolii ANU843 ${ }^{\mathrm{RR}}$ strains do not show an observable spot on a TLC plate from LCOs produced at $28^{\circ} \mathrm{C}$ in the presence of radiolabeled glucosamine, while the results obtained with HPLC analysis show that these strains produce relatively large amounts of (unlabeled) LCOs at this temperature.

Figure 2 shows that for both strains A1 and ANU843 ${ }^{\mathrm{RR}}$.pRI4003 the most intense peak (recorded at 206 $\mathrm{nm}$ absorbance) elutes later in the HPLC profile of LCOs produced at $12^{\circ} \mathrm{C}$ than in that for those produced at $28^{\circ} \mathrm{C}$. The presence of absorbance maxima at $260 \mathrm{~nm}$ (not shown) and $303 \mathrm{~nm}$ (Fig. 2A,B) in the HPLC profiles obtained from strain

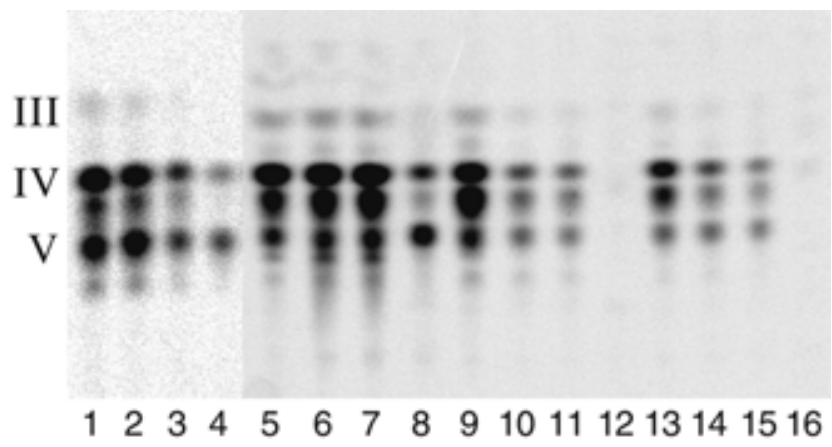

Fig. 1. Normal phase thin-layer chromatography (TLC) profile of radiolabeled lipo-chitin oligosaccharides (LCOs) produced by (lanes 1-4) wild-type Rhizobium leguminosarum bv. trifolii ANU843 ${ }^{\mathrm{RR}}$, (lanes 5-8) R. leguminosarum bv. trifolii ANU843 ${ }^{\mathrm{RR}}$.pRI4003, (lanes 9-12) R. leguminosarum bv. viciae $\mathrm{A} 1$, and (lanes 13-16) $R$. leguminosarum bv. viciae TOM, at (lanes $1,5,9,13) 6^{\circ} \mathrm{C}$, (lanes $\left.2,6,10,14\right) 12^{\circ} \mathrm{C}$, (lanes $3,7,11,15) 18^{\circ} \mathrm{C}$, and (lanes $\left.4,8,12,16\right) 28^{\circ} \mathrm{C}$. III, spots corresponding to $\mathrm{GlcNAc}_{3}$-containing LCOs; IV, spots corresponding to $\mathrm{GlcNAc}_{4}{ }^{-}$ containing LCOs; V, spots corresponding to $\mathrm{GlcNAc}_{5}$-containing LCOs. Lanes 1-4 originate from a different TLC plate than lanes 5-16. This explains the small difference in $R_{\mathrm{f}}$ values of the LCO spots on the two plates, e.g., the $R_{\mathrm{f}}$ values of the spots corresponding to the $\mathrm{GlcNAc}_{3^{-}}$ containing LCOs. 
A1 is consistent with the published structures (Ovtsyna et al. 1999; Spaink et al. 1991) and these probably correspond to LCOs having $\mathrm{C}_{18}$ fatty acids with two and three double bonds in conjugation with the carbonyl group, respectively. In addition to these absorbance maxima, the HPLC profiles from strain ANU843 ${ }^{\mathrm{RR}}$.pRI4003 also have peaks with $330 \mathrm{~nm}$ absorbance maxima (Fig. 2C,D) corresponding to LCOs bearing fatty acyl chains in which four double bonds are in conjugation with the carbonyl group as reported (Spaink et al. 1995a; van der Drift et al. 1996). The HPLC profiles at 303 and 330 $\mathrm{nm}$ (Fig. 2A and B, respectively) are different for the LCOs produced at the different growth temperatures.

To identify the LCO structures present in the HPLC fractions and to study the differences due to growth temperature in more detail, the HPLC fractions from $R$. leguminosarum bv. viciae $\mathrm{A} 1$ and $R$. leguminosarum bv. trifolii ANU843 ${ }^{\mathrm{RR}}$.pRI4003, which were chosen because of the large amount of LCOs they produce, were analyzed by fast atom bombardment mass spectrometry (FAB-MS) and nanoelectrospray quadrupole time-of-flight mass spectrometry (nanoES-Q-TOF-MS). To obtain structural information on individual LCO components, collision-induced dissociation tandem mass spectrometry (CID-MS/MS) was carried out. Fragmentation of an LCO precursor ion is induced on collision with air, and the fragment ions formed are recorded in the tandem mass spectrum. The MS analysis of LCOs is reviewed by van der Drift et al. (1998).
MS analysis of LCOs from R. leguminosarum bv. viciae A1.

FAB-MS was performed on all HPLC fractions collected from strain A1 obtained at 12 and $28^{\circ} \mathrm{C}$. FAB-MS is well suited for the rapid screening of LCOs, providing information on the molecular weight and on the presence of double bonds in the fatty acyl chain. "Thioglycerol adduct" ions are observed 108 mass units above the pseudomolecular ions in the FAB mass spectra when a double bond is present in the corresponding glycolipid and thioglycerol is used as the matrix (Fukuda et al. 1985). With FAB, LCO species ionize predominantly to give $[\mathrm{M}+\mathrm{H}]^{+}$pseudomolecular ions. The species identified from the FAB mass spectra, together with those assigned from the nanoES experiments (see below) are summarized in Table 1. If a peak could not be assigned without ambiguity, the relevant HPLC fraction was analyzed by FABMS with 3-nitrobenzyl alcohol as matrix, which contains a large amount of sodium. When the spectra run in 3nitrobenzyl alcohol were compared with those run in thioglycerol, the relevant LCO signals were shifted up in mass by 22 mass units, due to the formation of $[\mathrm{M}+\mathrm{Na}]^{+}$rather than $[\mathrm{M}+\mathrm{H}]^{+}$pseudomolecular ions, thus facilitating the assignment of the structures. Additional structural information from LCOs in the $12^{\circ} \mathrm{C}$ fraction 4 and $28^{\circ} \mathrm{C}$ fraction 3 was obtained by mild base de-esterification (see Table 1), which selectively removes $O$-acetyl groups. The MS shifts resulting from this treatment were used to determine the number of $O$-acetyl groups present in the different LCOs and to confirm the pro-
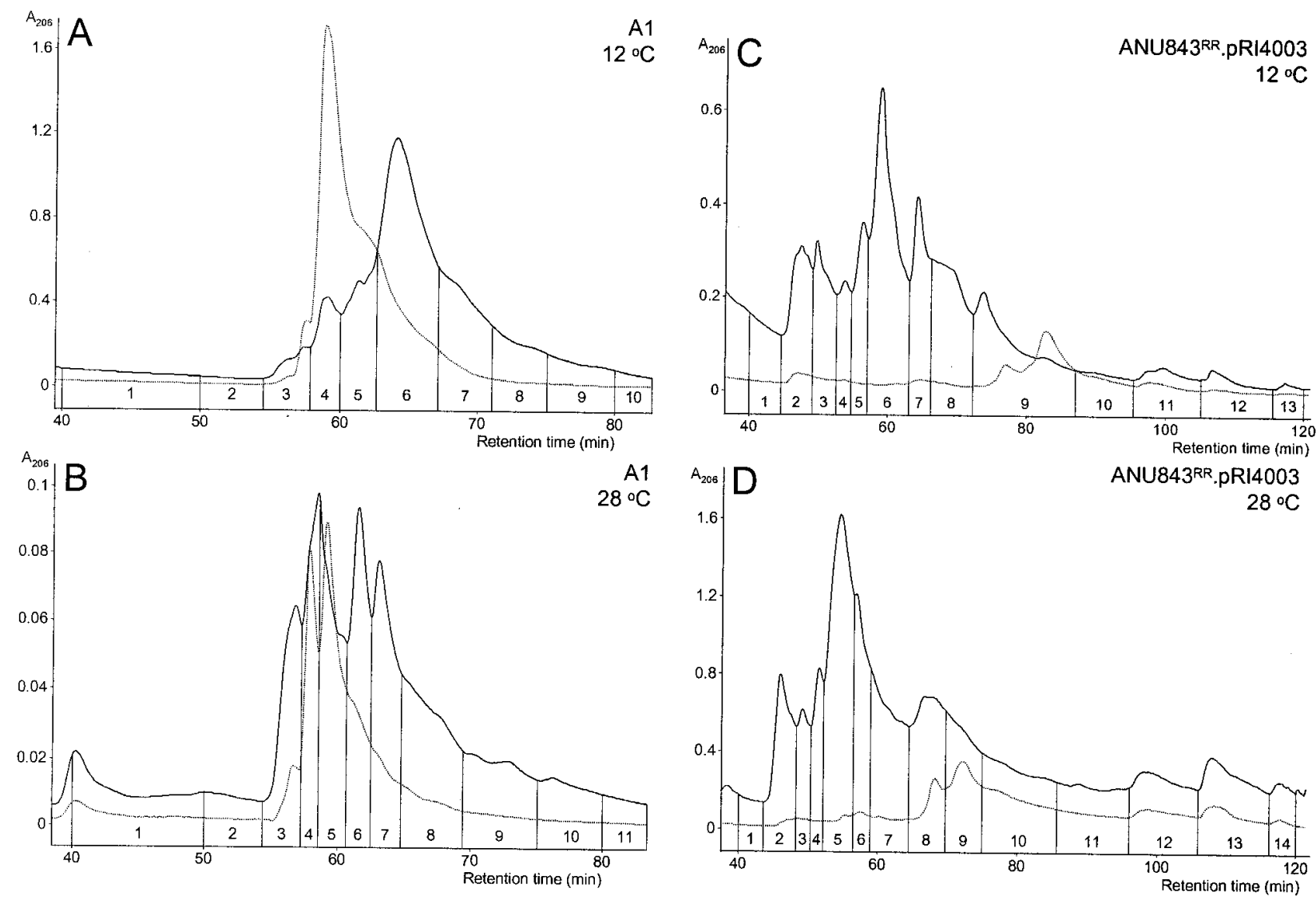

Fig. 2. High-performance liquid chromatography (HPLC) profiles of $n$-butanol extracts from (A,B) Rhizobium leguminosarum bv. viciae A1 and (C,D) R. leguminosarum bv. trifolii ANU843 ${ }^{\mathrm{RR}}$.pRI4003 obtained at growth temperatures of $(\mathbf{A}, \mathbf{C}) 12^{\circ} \mathrm{C}$ and $\left({ }^{\circ}\right) 28^{\circ} \mathbf{C}$. Absorbance was recorded at $206 \mathrm{~nm}$. Dotted lines correspond to (A,B) $303 \mathrm{~nm}$ and (C,D) $330 \mathrm{~nm}$ absorbance. Fractions were pooled as indicated. 
posed structures. To verify the presence of some minor species giving ions that are difficult to distinguish from the background in the FAB mass spectra, nanoES-Q-TOF-MS was performed because of its higher sensitivity and lower background. In addition, to obtain detailed structural information on individual LCO components, different pseudomolecular ions present in the mass spectra were analyzed by CID-MS/MS, with nanoES-Q-TOF-MS (Table 1). A rough indication of the relative amounts of the various LCOs produced was obtained based on the relative intensities of the corresponding pseudomolecular ions in the mass spectra together with consideration of the corresponding peak intensities at $206 \mathrm{~nm}$ in the HPLC chromatogram. The LCO components, however, are generally spread over several HPLC fractions so that a direct comparison is not straightforward. To compare the LCOs produced at the two temperatures more directly, composite representative pooled fractions (see Materials and Methods) were generated for the LCOs produced at each temperature and these were analyzed by MS. Different dilutions of the pooled fractions were prepared and analyzed with nanoES, FAB, and matrix-assisted laser desorption/ionization (MALDI) to obtain a series of spectra in which the relative intensities of the pseudomolecular ions for the different LCO components could be compared.

The results of the MS analysis of the individual HPLC fractions show that the major LCO components are produced at both temperatures, but some minor LCO components are produced at only one temperature (see Table 1). In the mass spectra of all HPLC fractions, ions corresponding to doubly acetylated, pentameric LCO species are present, but, importantly, with a significantly higher intensity in those fractions obtained from LCOs produced at $12^{\circ} \mathrm{C}$ than at $28^{\circ} \mathrm{C}$. These observations are consistent with the indications obtained from TLC and HPLC analyses and support the hypothesis that more nodX-mediated, doubly acetylated LCOs are produced at $12^{\circ} \mathrm{C}$

Table 1. Summary of lipo-chitin oligosaccharide (LCO) structures identified as being produced at 12 and $28^{\circ} \mathrm{C}$ by Rhizobium leguminosarum bv. viciae A1, analyzed by fast atom bombardment-mass spectrometry (FAB-MS) and nano-electrospray quadrupole time-of-flight mass spectrometry (nanoES-QTOF-MS) in combination with collision-induced dissociation tandem mass spectrometry (CID-MS/MS)

\begin{tabular}{|c|c|c|c|c|c|c|c|}
\hline LCO structure $^{a}$ & {$[\mathrm{M}+\mathrm{Na}]^{+}(m / z)$} & $12^{\circ} \mathrm{C}$ FAB $\#^{b}$ & $\mathbf{E S}^{\mathbf{c}}$ & $28^{\circ} \mathrm{C}$ FAB $\#^{b}$ & $\mathbf{E S}^{\mathbf{c}}$ & nanoES-MS/MS ${ }^{d}$ & $-\mathbf{A c} c^{\mathrm{e}}$ \\
\hline $\mathrm{V}\left(\mathrm{C}_{18: 0}, \mathrm{Ac}, \mathrm{Ac}\right)$ & 1364 & 10 & + & 10,11 & + & 12,28 & - \\
\hline $\mathrm{V}\left(\mathrm{C}_{18: 1}, \mathrm{Ac}, \mathrm{Ac}\right)$ & 1362 & $5-10$ & + & $1-11$ & + & 12,28 & + \\
\hline $\mathrm{V}\left(\mathrm{C}_{18: 3}, \mathrm{Ac}, \mathrm{Ac}\right)$ & 1358 & 5,6 & + & 5 & + & 12,28 & - \\
\hline $\mathrm{V}\left(\mathrm{C}_{18: 4}, \mathrm{Ac}, \mathrm{Ac}\right)$ & 1356 & $3-6$ & + & 5 & + & 12,28 & + \\
\hline $\mathrm{V}\left(\mathrm{C}_{16: 0}, \mathrm{Ac}, \mathrm{Ac}\right)$ & 1336 & 3,4 & + & 5 & & 12,28 & + \\
\hline $\mathrm{V}\left(\mathrm{C}_{18: 1-\mathrm{OH}}, \mathrm{Ac}\right)$ & 1336 & & & & & 12,28 & \\
\hline $\mathrm{V}\left(\mathrm{C}_{16: 1}, \mathrm{Ac}, \mathrm{Ac}\right)$ & 1334 & $1-3$ & + & - & + & 12,28 & - \\
\hline $\mathrm{V}\left(\mathrm{C}_{18: 2-\mathrm{OH}}, \mathrm{Ac}\right)$ & 1334 & & & & & 12,28 & \\
\hline $\mathrm{V}\left(\mathrm{C}_{18: 0}, \mathrm{Ac}\right)$ & 1322 & 10 & - & $9-11$ & - & - & - \\
\hline $\mathrm{V}\left(\mathrm{C}_{18: 1}, \mathrm{Ac}\right)$ & 1320 & $4-10$ & + & $1-11$ & + & 12 & + \\
\hline $\mathrm{V}\left(\mathrm{C}_{18: 1}, \text { redAc }\right)^{\mathrm{f}}$ & 1320 & & & & & 12 & \\
\hline $\mathrm{V}\left(\mathrm{C}_{18: 2}, \mathrm{Ac}\right)$ & 1318 & 4 & + & 5 & + & - & + \\
\hline $\mathrm{V}\left(\mathrm{C}_{18: 3}, \mathrm{Ac}\right)$ & 1316 & 4 & + & 5 & + & 12,28 & + \\
\hline$V\left(C_{18: 3}, \text { redAc }\right)^{f}$ & 1316 & & & & & 12 & \\
\hline $\mathrm{V}\left(\mathrm{C}_{18: 4}, \mathrm{Ac}\right)$ & 1314 & 3,4 & + & $3-5$ & + & 12,28 & + \\
\hline $\mathrm{V}\left(\mathrm{C}_{18: 4}, \operatorname{redAc}\right)^{\mathrm{f}}$ & 1314 & & & & & 12 & \\
\hline $\mathrm{V}\left(\mathrm{C}_{16: 0}, \mathrm{Ac}\right)$ & 1294 & 3,4 & + & 5 & + & 12,28 & + \\
\hline $\mathrm{V}\left(\mathrm{C}_{16: 0}, \text { redAc }\right)^{\mathrm{f}}$ & 1294 & & & & & 12,28 & \\
\hline $\mathrm{V}\left(\mathrm{C}_{16: 1}, \mathrm{Ac}\right)$ & 1292 & $1-4$ & + & $1-5$ & + & - & + \\
\hline $\mathrm{V}\left(\mathrm{C}_{18: 0}\right)$ & 1280 & - & - & 10 & - & - & - \\
\hline $\mathrm{V}\left(\mathrm{C}_{18: 1}\right)$ & 1278 & $4-8$ & + & $5-10$ & + & 12 & + \\
\hline $\operatorname{IV}\left(\mathrm{C}_{18: 1-\mathrm{OH}}, \mathrm{Ac}\right)$ & 1133 & 4,5 & + & 5 & + & 12 & + \\
\hline $\operatorname{IV}\left(\mathrm{C}_{18: 0}, \mathrm{Ac}\right)$ & 1119 & 10 & + & 10,11 & + & 12,28 & \\
\hline $\operatorname{IV}\left(\mathrm{C}_{18: 1}, \mathrm{Ac}\right)$ & 1117 & $4-10$ & + & $1-11$ & + & 12,28 & + \\
\hline $\operatorname{IV}\left(\mathrm{C}_{18: 2}, \mathrm{Ac}\right)$ & 1115 & 4,5 & + & 3 & + & 12,28 & + \\
\hline $\operatorname{IV}\left(\mathrm{C}_{18: 3}, \mathrm{Ac}\right)$ & 1113 & 5 & + & 3 & + & 12,28 & - \\
\hline $\operatorname{IV}\left(\mathrm{C}_{18: 4}, \mathrm{Ac}\right)$ & 1111 & $3-6$ & + & $1-5$ & + & 12,28 & + \\
\hline $\operatorname{IV}\left(\mathrm{C}_{16: 0}, \mathrm{Ac}\right)$ & 1091 & $3-6$ & + & $4-6$ & + & 12 & + \\
\hline $\operatorname{IV}\left(\mathrm{C}_{16: 1}, \mathrm{Ac}\right)$ & 1089 & $1-4$ & + & $1-5$ & + & 12 & + \\
\hline $\operatorname{IV}\left(\mathrm{C}_{18: 0}\right)$ & 1077 & 10 & - & 10,11 & - & - & - \\
\hline $\operatorname{IV}\left(\mathrm{C}_{18: 1}\right)$ & 1075 & $5-10$ & + & $6-10$ & + & 12 & - \\
\hline $\operatorname{IV}\left(\mathrm{C}_{18: 4}\right)$ & 1069 & 4 & + & 5 & - & 12 & + \\
\hline $\operatorname{IV}\left(\mathrm{C}_{14: 1-\mathrm{OH}}\right)$ & 1035 & 4 & + & 4,5 & + & 28 & - \\
\hline $\operatorname{III}\left(\mathrm{C}_{18: 1}, \mathrm{Ac}\right)$ & 914 & $6-10$ & + & $8-10$ & + & 12,28 & - \\
\hline $\operatorname{III}\left(\mathrm{C}_{18: 2}, \mathrm{Ac}\right)$ & 912 & 4 & + & - & - & - & + \\
\hline $\operatorname{III}\left(\mathrm{C}_{18: 1}\right)$ & 872 & $5-9$ & - & - & - & - & - \\
\hline
\end{tabular}

\footnotetext{
a Nomenclature (substituents listed "clockwise" in the order in which they appear in a two-dimensional depiction of the structure drawn with Haworth projections of the monosaccharides and starting with the fatty acid; Spaink 1992).

b High-performance liquid chromatography (HPLC) fraction number; LCOs observed as [M+H] $]^{+}$pseudomolecular ions with FAB-MS.

c nanoES-Q-TOF-MS performed on representative, composite HPLC fractions; LCOs observed as $[\mathrm{M}+\mathrm{Na}]{ }^{+}$pseudomolecular ions.,+ pseudomolecular ion observed; -, pseudomolecular ion not observed.

d nanoES-MS/MS performed on pseudomolecular ion from culture grown at 12 and/or 28 oC or not performed (-).

e De-O-acetylation, mild base de-esterification carried out on HPLC fraction 4 obtained at 12 oC and fraction 3 obtained at $28^{\circ} \mathrm{C}(+)$.

f redAc $=O$-acetyl group on reducing-terminal GlcNAc residue.
} 
than at $28^{\circ} \mathrm{C}$. Clearly, the relative amounts of the major LCOs produced are different at the two temperatures, indicating growth temperature dependence. For example, hardly any $\mathrm{HexNAc}_{3}$-containing LCOs are produced at $28^{\circ} \mathrm{C}$, while in HPLC fractions 8,9 , and 10 obtained at $12^{\circ} \mathrm{C}, \mathrm{HexNAc}_{3}$ LCOs are major components.

All LCO components that have recently been reported to be produced at $28^{\circ} \mathrm{C}$ (Ovtsyna et al. 1999) are observed. In addition, we have identified some extra, minor pseudomolecular ions corresponding to $\operatorname{III}\left(\mathrm{C}_{18: 1}\right), \operatorname{IV}\left(\mathrm{C}_{18: 4}\right), \operatorname{IV}\left(\mathrm{C}_{18: 0}\right), \mathrm{V}\left(\mathrm{C}_{18: 0}\right)$, $\mathrm{V}\left(\mathrm{C}_{16: 2}, \mathrm{Ac}\right), \mathrm{V}\left(\mathrm{C}_{16: 1}, \mathrm{Ac}\right), \mathrm{V}\left(\mathrm{C}_{18: 0}, \mathrm{Ac}\right)$, and $\mathrm{V}\left(\mathrm{C}_{16: 1}, \mathrm{Ac}, \mathrm{Ac}\right)$ produced at 12 and/or $28^{\circ} \mathrm{C}$. These LCOs were probably not observed by Ovtsyna et al. (1999) since they only induced the bacteria to produce LCOs at $28^{\circ} \mathrm{C}$ and did not collect and analyze all HPLC fractions.

The nanoES-Q-TOF mass spectra of the representative pooled HPLC fractions derived from strain A1 at 12 and $28^{\circ} \mathrm{C}$ (Fig. 3A,B) obtained under the same instrumental conditions contain mainly $[\mathrm{M}+\mathrm{Na}]^{+}$ions and clearly show differences in relative ion intensities for LCOs produced at the different temperatures. Remarkably, the ion at $\mathrm{m} / \mathrm{z}$ 1362.6 corresponding to $\mathrm{V}\left(\mathrm{C}_{18: 1}, \mathrm{Ac}, \mathrm{Ac}\right)$ is the second most intense ion in the spectrum of LCOs produced at $12^{\circ} \mathrm{C}$, while in the spectrum of LCOs produced at $28^{\circ} \mathrm{C}$ the same ion is present at much lower intensity, confirming that relatively more nodX-mediated, doubly acetylated, pentameric LCOs are produced at $12^{\circ} \mathrm{C}$ than at $28^{\circ} \mathrm{C}$. In addition, other nodX-mediated, doubly acetylated $\mathrm{LCOs}\left(\mathrm{V}\left(\mathrm{C}_{16: 0}, \mathrm{Ac}, \mathrm{Ac}\right)\right.$ at $m / z \quad 1336.7$ and $\mathrm{V}\left(\mathrm{C}_{18: 4}, \mathrm{Ac}, \mathrm{Ac}\right)$ at $\left.m / z, 1356.7\right)$ also yield more intense pseudomolecular ions in the spectrum of the LCOs produced at $12^{\circ} \mathrm{C}$. In keeping with what was observed through FAB analysis of the individual HPLC fractions, the pseudomolecular ion for the $\mathrm{HexNAc}_{3}$-containing LCO (III $\left(\mathrm{C}_{18: 1}, \mathrm{Ac}\right)$ at $\left.m / z, 914.6\right)$ is more abundant in the nanoES spectra of the LCOs produced at $12^{\circ} \mathrm{C}$ than in that of those produced at $28^{\circ} \mathrm{C}$.

The FAB and MALDI spectra of the pooled HPLC fractions (not shown) yield results that are directly comparable with those from the nanoES spectra. Instrumental conditions were varied and different dilutions were analyzed to study their influence on the relative intensities of the ions, and only small differences were observed.

In summary, $R$. leguminosarum bv. viciae A1 produces relatively larger amounts of nodX-mediated, doubly acetylated, pentameric LCOs at $12^{\circ} \mathrm{C}$ than at $28^{\circ} \mathrm{C}$. To see whether this is observed with other nodX-containing bacteria, the HPLC fractions from the large-scale culture of $R$. leguminosarum bv. trifolii ANU843 ${ }^{\mathrm{RR}}$.pRI4003 that was induced to produce LCOs at $12^{\circ} \mathrm{C}$ and $28^{\circ} \mathrm{C}$ were also analyzed following the same procedures used for strain $\mathrm{A} 1$.

\section{MS analysis of LCOs from $R$. leguminosarum bv. trifolii $\mathrm{ANU843}^{\mathrm{RR}}$.pRI4003.}

All individual HPLC fractions from strain ANU843 ${ }^{R R}$.pRI4003 obtained at 12 and $28^{\circ} \mathrm{C}$ were submitted to FAB-MS analysis and some were also analyzed by nanoESQ-TOF-MS/MS. In addition, FAB-MS, MALDI-TOF-MS, and nanoES-Q-TOF-MS combined with CID-MS/MS were performed on the two composite, representative, pooled HPLC fractions of LCOs produced at 12 and $28^{\circ} \mathrm{C}$. The species identified from the FAB mass spectra together with those assigned from the nanoES experiments (see below) are summarized in Table 2.

Doubly acetylated, pentameric LCOs are observed in the HPLC fractions obtained at both temperatures. However, in the FAB mass spectra of HPLC fractions 6,7 , and 8 obtained
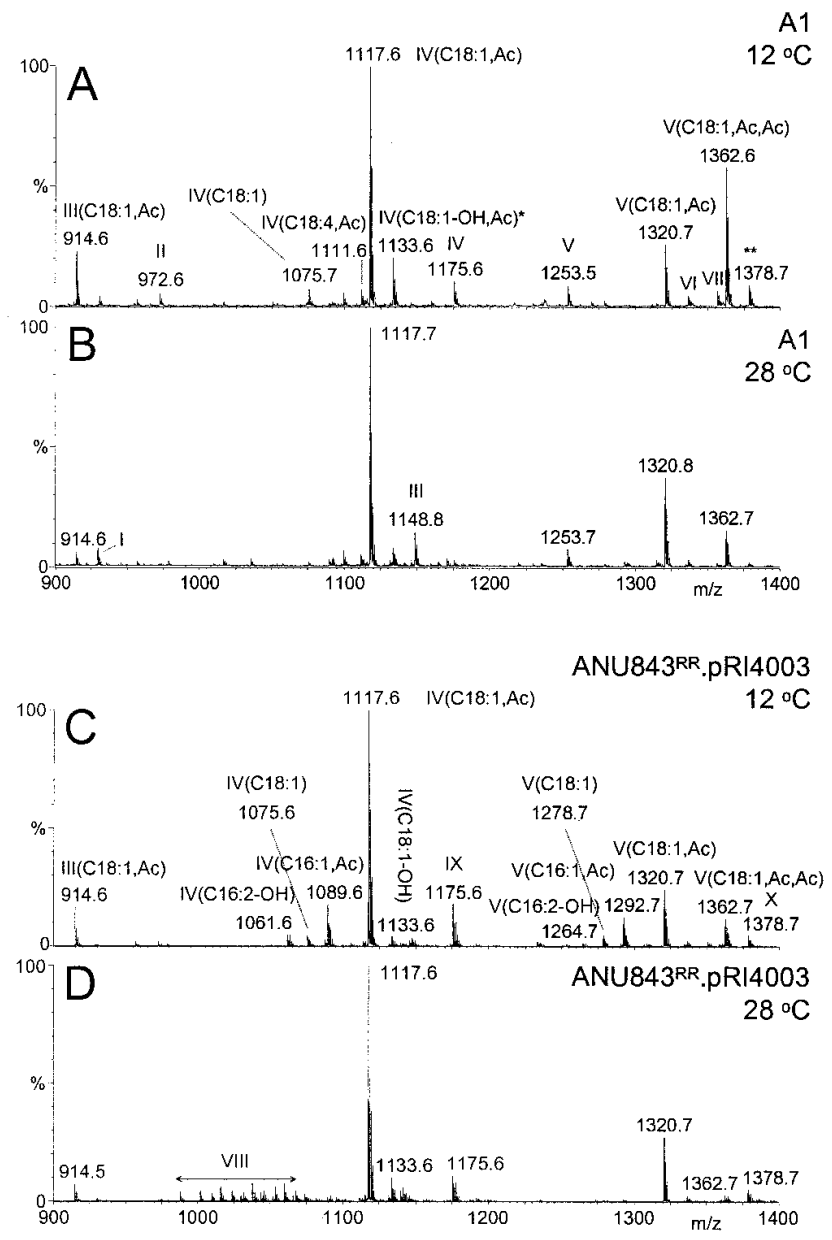

Fig. 3. Positive ion mode nano-electrospray quadrupole time-of-flight (nanoES-Q-TOF) mass spectra $(\mathrm{m} / \mathrm{z}, 900-1400)$ of the representative composite high-performance liquid chromatography (HPLC) fractions from $(\mathbf{A}, \mathbf{B})$ Rhizobium leguminosarum bv. viciae $\mathrm{A} 1$ and $(\mathbf{C}, \mathbf{D})$ R. leguminosarum bv. trifolii ANU843 ${ }^{\mathrm{RR}}$.pRI4003 produced at $(\mathbf{A}, \mathbf{C}) 12^{\circ} \mathrm{C}$ and (B,D) $28^{\circ} \mathrm{C}$. Instrumental settings: capillary voltage (A,B) $2500 \mathrm{~V}$ and (C,D) $1700 \mathrm{~V}$, cone voltage $100 \mathrm{~V}$. Summary of assignments is given in Table 1 for $R$. leguminosarum bv. viciae A1 and in Table 2 for $R$. leguminosarum bv. trifolii ANU843 ${ }^{\mathrm{RR}}$.pRI4003. Peak assignments based on MS/MS data: I, m/z 929.6 polyester $\mathrm{HO}\left(-\mathrm{CH}_{2}-\mathrm{CH}_{2}-\mathrm{CH}_{2}-\mathrm{CO}-\mathrm{O}\right)_{9}-\mathrm{CH}_{2}-$ $\mathrm{CH}_{3}+\mathrm{Na}^{+}$; II, $m / z$ 972.6 adduct of $\mathrm{III}\left(\mathrm{C}_{18: 1}, \mathrm{Ac}\right)+\mathrm{Na}^{+}$and 58 mass units (perhaps sodium chloride, although the low ion intensity makes it difficult to be certain); III, $\mathrm{m} / z 1448.8$ unassigned contaminant (from its MS/MS spectrum, not a lipo-chitin oligosaccharide [LCO]); IV, $\mathrm{m} / z$ 1175.6 adduct of $\mathrm{IV}\left(\mathrm{C}_{18: 1}, \mathrm{Ac}\right)+\mathrm{Na}^{+}$and 58 mass units (perhaps sodium chloride, although the low ion intensity makes it difficult to be certain); $\mathrm{V}, \mathrm{m} / z, 1253.5$ adduct of $\mathrm{IV}\left(\mathrm{C}_{18: 1}, \mathrm{Ac}\right)+\mathrm{Na}^{+}$and 136 mass units; $\mathrm{VI}, \mathrm{m} / z$ 1336.7 V(C $\left.\mathrm{C}_{16: 0}, \mathrm{Ac}, \mathrm{Ac}\right)$; VII, $m / z$ 1356.7 V(C $\mathrm{C}_{18: 4}$, Ac,Ac); VIII, ions not corresponding to LCOs that have also been observed in the late-eluting HPLC fractions $11-14$ obtained at $28^{\circ} \mathrm{C}$; IX, $\mathrm{m} / \mathrm{z} 1175.6$ adduct of $\mathrm{IV}\left(\mathrm{C}_{18: 1}, \mathrm{Ac}\right)+\mathrm{Na}^{+}$and sodium chloride; $\mathrm{X}, \mathrm{m} / \mathrm{z} 1378.7$ adduct of $\mathrm{V}\left(\mathrm{C}_{18: 1}, \mathrm{Ac}\right)+\mathrm{Na}^{+}$and sodium chloride. *, also shown to correspond to potassium-cationized $\operatorname{IV}\left(\mathrm{C}_{18: 1}, \mathrm{Ac}\right)$. ${ }^{* *}$, also shown to correspond to potassium-cationized $\mathrm{V}\left(\mathrm{C}_{18: 1}, \mathrm{Ac}, \mathrm{Ac}\right)$. 
Table 2. Summary of lipo-chitin oligosaccharide (LCO) structures identified as being produced at 12 and $28^{\circ} \mathrm{C}$ by Rhizobium leguminosarum bv. trifolii ANU843 ${ }^{\mathrm{RR}}$.pRI4003, analyzed by fast atom bombardment-mass spectrometry (FAB-MS) and nano-electrospray quadrupole time-of-flight mass spectrometry (nanoES-Q-TOF-MS) in combination with collision-induced dissociation tandem mass spectrometry (CID-MS/MS)

\begin{tabular}{|c|c|c|c|c|c|c|c|c|c|c|c|c|c|}
\hline LCO structure ${ }^{\mathrm{a}}$ & $\begin{array}{c}{[\mathrm{M}+\mathrm{Na}]^{+}} \\
(m / z)\end{array}$ & $\begin{array}{c}12^{\circ} \mathrm{C} \\
\text { FAB } \#^{b}\end{array}$ & $\mathbf{E S}^{\mathbf{c}}$ & $\begin{array}{c}28^{\circ} \mathrm{C} \\
\text { FAB } \#^{\mathbf{b}}\end{array}$ & $\mathbf{E S}^{\mathbf{c}}$ & $\begin{array}{l}\text { nanoES- } \\
\text { MS/MS }^{d}\end{array}$ & $\begin{array}{c}\text { LCO } \\
\text { structure }^{\mathbf{a}}\end{array}$ & $\begin{array}{c}{[\mathrm{M}+\mathrm{Na}]^{+}} \\
(\mathrm{m} / z)\end{array}$ & $\begin{array}{c}12^{\circ} \mathrm{C} \\
\text { FAB } \#^{b}\end{array}$ & $\mathbf{E S}^{\mathbf{c}}$ & $\begin{array}{c}28^{\circ} \mathrm{C} \\
\text { FAB } \#^{b}\end{array}$ & $\mathbf{E S}^{\mathbf{c}}$ & $\begin{array}{l}\text { nanoES- } \\
\text { MS/MS }^{d}\end{array}$ \\
\hline $\mathrm{V}\left(\mathrm{C}_{20: 0}, \mathrm{Ac}, \mathrm{Ac}\right)$ & 1392 & - & + & - & - & 12 & $\mathrm{~V}\left(\mathrm{C}_{16: 3-\mathrm{OH}}\right)$ & 1262 & 4 & + & 3,4 & - & - \\
\hline $\mathrm{V}\left(\mathrm{C}_{20: 1}, \mathrm{Ac}, \mathrm{Ac}\right)$ & 1390 & 11 & + & - & + & 12 & $\mathrm{~V}\left(\mathrm{C}_{16: 1}\right)$ & 1250 & 2,3 & + & 2 & - & - \\
\hline $\mathrm{V}\left(\mathrm{C}_{22: 2-\mathrm{OH}}, \mathrm{Ac}\right)$ & 1390 & & & & & 28 & $\operatorname{IV}\left(\mathrm{C}_{20: 0-\mathrm{OH}}, \mathrm{Ac}\right)$ & 1163 & 3 & + & 2 & + & - \\
\hline $\mathrm{V}\left(\mathrm{C}_{20: 2}, \mathrm{Ac}, \mathrm{Ac}\right)$ & 1388 & 11 & + & - & + & 12,28 & $\mathrm{IV}\left(\mathrm{C}_{20: 1-\mathrm{OH}}, \mathrm{Ac}\right)$ & 1161 & - & + & - & + & - \\
\hline $\mathrm{V}\left(\mathrm{C}_{20: 3}, \mathrm{Ac}, \mathrm{Ac}\right)$ & 1386 & $9-13$ & + & $9-11$ & + & 12,28 & $\mathrm{IV}\left(\mathrm{C}_{18: 2-\mathrm{OH}}, \mathrm{Ac}, \mathrm{Et}\right)$ & 1159 & 11,12 & + & 13,14 & + & 28 \\
\hline $\mathrm{V}\left(\mathrm{C}_{20: 4}, \mathrm{Ac}, \mathrm{Ac}\right)$ & 1384 & $9-13$ & + & $8-10$ & + & 12,28 & $\mathrm{IV}\left(\mathrm{C}_{20: 2-\mathrm{OH}}, \mathrm{Ac}\right)$ & 1159 & & & & & 12,28 \\
\hline $\mathrm{V}\left(\mathrm{C}_{20: 5}, \mathrm{Ac}, \mathrm{Ac}\right)$ & 1382 & 12 & + & - & + & 12,28 & $\mathrm{IV}\left(\mathrm{C}_{20: 3-\mathrm{OH}}, \mathrm{Ac}\right)$ & 1157 & - & + & 13,14 & + & 28 \\
\hline $\mathrm{V}\left(\mathrm{C}_{20: 0-\mathrm{OH}}, \mathrm{Ac}\right)$ & 1366 & 3 & + & - & + & 12,28 & $\mathrm{IV}\left(\mathrm{C}_{20: 4-\mathrm{OH}}, \mathrm{Ac}\right)$ & 1155 & - & + & 12,13 & + & 28 \\
\hline $\mathrm{V}\left(\mathrm{C}_{18: 0}, \mathrm{Ac}, \mathrm{Ac}\right)$ & 1364 & $9-13$ & + & 9,13 & + & 12,28 & $\mathrm{IV}\left(\mathrm{C}_{18: 0}, \mathrm{Ac}, \mathrm{Et}\right)$ & 1147 & $11-12$ & + & 13 & + & 12,28 \\
\hline $\mathrm{V}\left(\mathrm{C}_{20: 1-\mathrm{OH}}, \mathrm{Ac}\right)$ & 1364 & & & & & 28 & $\operatorname{IV}\left(\mathrm{C}_{20: 0}, \mathrm{Ac}\right)$ & 1147 & & & & & 12,28 \\
\hline $\mathrm{V}\left(\mathrm{C}_{18: 1}, \mathrm{Ac}, \mathrm{Ac}\right)$ & 1362 & $6-13$ & + & $5-10,13$ & + & 12,28 & $\mathrm{IV}\left(\mathrm{C}_{18: 1}, \mathrm{Ac}, \mathrm{Et}\right)$ & 1145 & $11-12$ & + & 13,14 & + & 12,28 \\
\hline $\mathrm{V}\left(\mathrm{C}_{20: 2-\mathrm{OH}}, \mathrm{Ac}\right)$ & 1362 & & & & & 28 & $\operatorname{IV}\left(\mathrm{C}_{20: 1}, \mathrm{Ac}\right)$ & 1145 & & & & & 12,28 \\
\hline $\mathrm{V}\left(\mathrm{C}_{18: 2}, \mathrm{Ac}, \mathrm{Ac}\right)$ & 1360 & $11-13$ & + & 13 & + & 12,28 & $\mathrm{IV}\left(\mathrm{C}_{20: 2}, \mathrm{Ac}\right)$ & 1143 & 12 & + & 12,13 & + & 12,28 \\
\hline $\mathrm{V}\left(\mathrm{C}_{20: 3-\mathrm{OH}}, \mathrm{Ac}\right)$ & 1360 & & & & & 12,28 & $\operatorname{IV}\left(\mathrm{C}_{20: 3}, \mathrm{Ac}\right)$ & 1141 & $9-12$ & + & $10-13$ & + & 12,28 \\
\hline $\mathrm{V}\left(\mathrm{C}_{18: 3}, \mathrm{Ac}, \mathrm{Ac}\right)$ & 1358 & $11-13$ & + & - & + & 12,28 & $\operatorname{IV}\left(\mathrm{C}_{20: 4}, \mathrm{Ac}\right)$ & 1139 & $9-12$ & + & $7-10$ & + & 12,28 \\
\hline $\mathrm{V}\left(\mathrm{C}_{20: 4-\mathrm{OH}}, \mathrm{Ac}\right)$ & 1358 & & & & & 12,28 & $\operatorname{IV}\left(\mathrm{C}_{20: 5}, \mathrm{Ac}\right)$ & 1137 & $8-10$ & + & 6,7 & + & 12,28 \\
\hline $\mathrm{V}\left(\mathrm{C}_{16: 1-\mathrm{OH}}, \mathrm{Ac}, \mathrm{Ac}\right)$ & 1350 & - & + & - & + & 12 & $\operatorname{IV}\left(\mathrm{C}_{18: 0-\mathrm{OH}}, \mathrm{Ac}\right)$ & 1135 & $1-3$ & + & 5 & + & 12,28 \\
\hline $\mathrm{V}\left(\mathrm{C}_{18: 0}, \mathrm{Ac}, \mathrm{Et}\right)$ & 1350 & & & & & 12,28 & $\operatorname{IV}\left(\mathrm{C}_{18: 1-\mathrm{OH}}, \mathrm{Ac}\right)$ & 1133 & $1-4$ & + & 3-7 & + & 12,28 \\
\hline $\mathrm{V}\left(\mathrm{C}_{20: 0}, \mathrm{Ac}\right)$ & 1350 & & & & & 12,28 & $\operatorname{IV}\left(\mathrm{C}_{18: 2-\mathrm{OH}}, \mathrm{Ac}\right)$ & 1131 & 13 & + & $5-9,12-14$ & + & 28 \\
\hline $\mathrm{V}\left(\mathrm{C}_{16: 2-\mathrm{OH}}, \mathrm{Ac}, \mathrm{Ac}\right)$ & 1348 & 7,8 & + & $5-7,9$ & + & 12,28 & $\operatorname{IV}\left(C_{22: 1}\right)$ & 1131 & & & & & 28 \\
\hline $\mathrm{V}\left(\mathrm{C}_{18: 1}, \mathrm{Ac}, \mathrm{Et}\right)$ & 1348 & & & & & 12,28 & $\operatorname{IV}\left(\mathrm{C}_{22: 2}\right)$ & 1129 & 13 & + & 13 & + & - \\
\hline $\mathrm{V}\left(\mathrm{C}_{20: 1}, \mathrm{Ac}\right)$ & 1348 & & & & & 12,28 & $\operatorname{IV}\left(\mathrm{C}_{18: 0}, \mathrm{Ac}\right)$ & 1119 & $9-12$ & + & $8-11$ & + & 12 \\
\hline $\mathrm{V}\left(\mathrm{C}_{20: 2}, \mathrm{Ac}\right)$ & 1346 & 8 & - & - & + & 28 & $\operatorname{IV}\left(\mathrm{C}_{18: 1}, \mathrm{Ac}\right)$ & 1117 & $5-12$ & + & $4-13$ & + & 28 \\
\hline $\mathrm{V}\left(\mathrm{C}_{20: 3}, \mathrm{Ac}\right)$ & 1344 & - & - & - & + & 28 & $\operatorname{IV}\left(\mathrm{C}_{18: 2}, \mathrm{Ac}\right)$ & 1115 & $5-7$ & + & 4,5 & + & 28 \\
\hline $\mathrm{V}\left(\mathrm{C}_{20: 4}, \mathrm{Ac}\right)$ & 1342 & 5,11 & + & - & + & 28 & $\operatorname{IV}\left(\mathrm{C}_{18: 3}, \mathrm{Ac}\right)$ & 1113 & 4 & + & 3,4 & + & 28 \\
\hline $\mathrm{V}\left(\mathrm{C}_{16: 0}, \mathrm{Ac}, \mathrm{Ac}\right)$ & 1336 & $3-5$ & + & $2-4$ & + & 12 & $\operatorname{IV}\left(\mathrm{C}_{18: 4}, \mathrm{Ac}\right)$ & 1111 & 4 & + & 3 & + & 28 \\
\hline $\mathrm{V}\left(\mathrm{C}_{18: 1-\mathrm{OH}}, \mathrm{Ac}\right)$ & 1336 & & & & & 12,28 & $\mathrm{IV}\left(\mathrm{C}_{16: 0-\mathrm{OH}}, \mathrm{Ac}\right)$ & 1107 & 3 & + & - & + & 12,28 \\
\hline $\mathrm{V}\left(\mathrm{C}_{16: 1}, \mathrm{Ac}, \mathrm{Ac}\right)$ & 1334 & $2-5$ & + & 4 & + & 12 & $\operatorname{IV}\left(\mathrm{C}_{16: 1-\mathrm{OH}}, \mathrm{Ac}\right)$ & 1105 & 1,2 & + & 1 & + & 12,28 \\
\hline $\mathrm{V}\left(\mathrm{C}_{18: 2-\mathrm{OH}}, \mathrm{Ac}\right)$ & 1334 & & & & & 12,28 & $\operatorname{IV}\left(C_{20: 1}\right)$ & 1103 & $9-12$ & $+{ }^{\mathrm{f}}$ & $8-13$ & $t^{\mathrm{f}, \mathrm{g}}$ & 12,28 \\
\hline $\mathrm{V}\left(\mathrm{C}_{16: 2}, \mathrm{Ac}, \mathrm{Ac}\right)$ & 1332 & 5 & + & - & + & 12 & $\operatorname{IV}\left(\mathrm{C}_{20: 2}\right)$ & 1101 & $6-12$ & $+t^{\mathrm{f}}$ & $5-13$ & $+^{\mathrm{f}}$ & 12,28 \\
\hline $\mathrm{V}\left(\mathrm{C}_{18: 3-\mathrm{OH}}, \mathrm{Ac}\right)$ & 1332 & & & & & 12,28 & $\operatorname{IV}\left(\mathrm{C}_{20: 3}\right)$ & 1099 & $6-10$ & $-{ }^{\mathrm{h}}$ & $5-14$ & $+^{f, g}$ & 12,28 \\
\hline $\mathrm{V}\left(\mathrm{C}_{18: 0}, \mathrm{Ac}\right)$ & 1322 & $8-12$ & + & 13 & + & - & $\operatorname{IV}\left(\mathrm{C}_{16: 0}, \mathrm{Ac}\right)$ & 1091 & 4,5 & + & 3,4 & + & - \\
\hline $\mathrm{V}\left(\mathrm{C}_{18: 1}, \mathrm{Ac}\right)$ & 1320 & $4-13$ & + & $4-13$ & + & 28 & $\operatorname{IV}\left(\mathrm{C}_{16: 1}, \mathrm{Ac}\right)$ & 1089 & $2-4,11$ & + & $1-3,10,11$ & + & - \\
\hline $\mathrm{V}\left(\mathrm{C}_{18: 2}, \mathrm{Ac}\right)$ & 1318 & 4,5 & + & $3-5$ & + & - & $\operatorname{IV}\left(\mathrm{C}_{16: 2}, \mathrm{Ac}\right)$ & 1087 & 2,3 & + & - & + & - \\
\hline $\mathrm{V}\left(\mathrm{C}_{18: 3}, \mathrm{Ac}\right)$ & 1316 & 4 & + & 3 & - & - & $\operatorname{IV}\left(\mathrm{C}_{14: 0-\mathrm{OH}}, \mathrm{Ac}\right)$ & 1079 & 1 & + & 1 & + & 12,28 \\
\hline $\mathrm{V}\left(\mathrm{C}_{18: 4}, \mathrm{Ac}\right)$ & 1314 & 2 & - & 1,2 & - & - & $\operatorname{IV}\left(\mathrm{C}_{18: 0}\right)$ & 1077 & $8-11$ & $+{ }^{\mathrm{f}}$ & 8,9 & $+{ }^{\mathrm{f}}$ & 28 \\
\hline $\mathrm{V}\left(\mathrm{C}_{16: 0-\mathrm{OH}}, \mathrm{Ac}\right)$ & 1310 & 3 & + & 2,3 & + & 12,28 & $\operatorname{IV}\left(\mathrm{C}_{18: 1}\right)$ & 1075 & $4-10$ & $+{ }^{\mathrm{f}}$ & $3-11$ & $+^{\mathrm{f}}$ & 28 \\
\hline $\mathrm{V}\left(\mathrm{C}_{14: 0}, \mathrm{Ac}, \mathrm{Ac}\right)$ & 1308 & 2,3 & + & - & + & 12 & $\operatorname{IV}\left(\mathrm{C}_{18: 2}\right)$ & 1073 & 2 & $+{ }^{\mathrm{f}}$ & 4 & + & - \\
\hline $\mathrm{V}\left(\mathrm{C}_{16: 1-\mathrm{OH}}, \mathrm{Ac}\right)$ & 1308 & & & & & 12,28 & $\operatorname{IV}\left(\mathrm{C}_{18: 3}\right)$ & 1071 & 2,3 & $+{ }^{f}$ & - & - & - \\
\hline $\mathrm{V}\left(\mathrm{C}_{14: 1-\mathrm{OH}}\right.$, red $\left.\mathrm{Ac}^{\mathrm{e}}, \mathrm{Et}\right)$ & 1308 & & & & & 28 & $\operatorname{IV}\left(\mathrm{C}_{16: 1-\mathrm{OH}}\right)$ & 1063 & $1-3$ & + & 1 & + & 12 \\
\hline $\mathrm{V}\left(\mathrm{C}_{14: 1}, \mathrm{Ac}, \mathrm{Ac}\right)$ & 1306 & $1-3$ & + & - & + & 12 & $\operatorname{IV}\left(\mathrm{C}_{16: 2-\mathrm{OH}}\right)$ & 1061 & 1,2 & + & 1 & + & 12 \\
\hline $\mathrm{V}\left(\mathrm{C}_{16: 2-\mathrm{OH}}, \mathrm{Ac}\right)$ & 1306 & & & & & 12,28 & $\operatorname{IV}\left(C_{16: 0}\right)$ & 1049 & 4,5 & $+{ }^{\mathrm{f}}$ & 3,4 & $++^{\mathrm{f}}$ & - \\
\hline $\mathrm{V}\left(\mathrm{C}_{20: 2}\right)$ & 1304 & $5-7$ & + & $4-6$ & + & 28 & $\operatorname{IV}\left(\mathrm{C}_{16: 1}\right)$ & 1047 & $2-5$ & $+{ }^{f}$ & $1-3$ & $+{ }^{\mathrm{f}}$ & - \\
\hline $\mathrm{V}\left(\mathrm{C}_{20: 3}\right)$ & 1302 & 5,12 & + & 4 & - & - & $\operatorname{IV}\left(\mathrm{C}_{16: 2}\right)$ & 1045 & 2 & $t^{\mathrm{f}}$ & $1-3$ & $t^{\mathrm{f}}$ & - \\
\hline $\mathrm{V}\left(\mathrm{C}_{16: 0}, \mathrm{Ac}\right)$ & 1294 & 4 & + & 3,4 & + & 12 & $\mathrm{III}\left(\mathrm{C}_{18: 0}, \mathrm{Ac}\right)$ & 916 & $9-12$ & + & $9-13$ & $+^{g}$ & 12,28 \\
\hline $\mathrm{V}\left(\mathrm{C}_{16: 1}, \mathrm{Ac}\right)$ & 1292 & $2-4$ & + & $1-4$ & + & 12 & $\operatorname{III}\left(\mathrm{C}_{18: 1}, \mathrm{Ac}\right)$ & 914 & $5-9$ & + & 4-11 & + & 12,28 \\
\hline $\mathrm{V}\left(\mathrm{C}_{16: 2}, \mathrm{Ac}\right)$ & 1290 & 2 & + & - & - & 12 & $\mathrm{III}\left(\mathrm{C}_{18: 2}, \mathrm{Ac}\right)$ & 912 & 5,6 & + & $3-5$ & $+^{\mathrm{g}}$ & 12,28 \\
\hline $\mathrm{V}\left(\mathrm{C}_{14: 0-\mathrm{OH}}, \mathrm{Ac}\right)$ & 1282 & 1 & + & - & - & - & $\mathrm{III}\left(\mathrm{C}_{18: 1}\right)$ & 872 & 6,7 & $++^{\mathrm{f}}$ & $5-7$ & - & - \\
\hline $\mathrm{V}\left(\mathrm{C}_{18: 0}\right)$ & 1280 & 8 & + & - & + & - & $\operatorname{III}\left(\mathrm{C}_{18: 2}\right)$ & 870 & 4,6 & $+{ }^{f}$ & $4-7$ & - & - \\
\hline $\mathrm{V}\left(\mathrm{C}_{18: 1}\right)$ & 1278 & $4-8$ & + & $3-10$ & + & - & $\operatorname{III}\left(\mathrm{C}_{18: 3}\right)$ & 868 & 2 & $+^{f}$ & 1 & - & - \\
\hline $\mathrm{V}\left(\mathrm{C}_{18: 2}\right)$ & 1276 & 2 & + & 2 & + & - & $\operatorname{III}\left(\mathrm{C}_{14: 0}, \mathrm{Ac}\right)$ & 860 & - & + & 2,3 & - & 12 \\
\hline $\mathrm{V}\left(\mathrm{C}_{16: 1-\mathrm{OH}}\right)$ & 1266 & 1 & + & 2 & + & 12 & $\mathrm{III}\left(\mathrm{C}_{14: 1}, \mathrm{Ac}\right)$ & 858 & 1 & + & 2,3 & - & 12 \\
\hline $\mathrm{V}\left(\mathrm{C}_{16: 2-\mathrm{OH}}\right)$ & 1264 & 1,2 & + & 2 & + & 12 & & & & & & & \\
\hline
\end{tabular}

a Nomenclature (substituents listed "clockwise" in the order in which they appear in a two-dimensional depiction of the structure drawn with Haworth projections of the monosaccharides and starting with the fatty acid; Spaink 1992).

b High-performance liquid chromatography (HPLC) fraction number, LCOs observed as $[\mathrm{M}+\mathrm{H}]^{+}$pseudomolecular ions by FAB-MS.

c nanoES-TOF-MS performed on representative composite samples, LCOs observed as $[\mathrm{M}+\mathrm{Na}]^{+}$pseudomolecular ions. + , pseudomolecular ion observed; -, pseudomolecular ion not observed.

d NanoES-MS/MS performed on pseudomolecular ion from culture grown at 12 and/or 28 oC or not performed (-).

e $\operatorname{RedAc}=O$-acetyl group on reducing-terminal GlcNAc residue.

$\mathrm{f}$ Ion observed at very low intensity in nanoES mass spectrum relative to ion intensity observed in FAB mass spectrum, indicating that this ion is the result of cleavage of an $O$-acetyl group during FAB ionization.

$\mathrm{g}$ Ion also shown to correspond to a fragment ion $\left(\mathrm{B}_{4}\right)$.

$\mathrm{h}$ Ion shown to correspond to a fragment ion $\left(\mathrm{B}_{4}\right)$. 
at $12^{\circ} \mathrm{C}$, a pseudomolecular ion at $\mathrm{m} / \mathrm{z}, 1340.7$ corresponding to the major doubly acetylated $\mathrm{LCO} \mathrm{V}\left(\mathrm{C}_{18: 1}, \mathrm{Ac}, \mathrm{Ac}\right)$ is present as one of the major ions, while this ion is only observed as a minor ion in the spectra from LCOs obtained at $28^{\circ} \mathrm{C}$, indicating, as do the results of the TLC analysis, that strain ANU843 ${ }^{\mathrm{RR}}$.pRI4003 produces a larger relative amount of nodX-mediated, doubly acetylated LCOs at $12^{\circ} \mathrm{C}$ than at $28^{\circ} \mathrm{C}$. In line with the results obtained from strains $\mathrm{A} 1$ and TOM, the nodX-mediated acetyl group is only attached to pentameric LCOs produced at either of the two temperatures. This acetyl group is attached to 18 different LCO species produced at $12^{\circ} \mathrm{C}$ and only to 10 produced at $28^{\circ} \mathrm{C}$, while $28^{\circ} \mathrm{C}$ is the temperature at which more LCOs are produced, suggesting a higher activity of $\operatorname{nod} X$ at the lower temperature.

To compare the relative amounts of the LCO structures present more directly, aliquots of the HPLC fractions obtained at each temperature were pooled to yield representative composite fractions of LCOs produced at each of the two temperatures and were analyzed by different MS techniques. Additional CID-MS/MS analyses of many of the pseudomolecular ions in the composite fractions were performed to determine the structures of most of the individual LCO components (see Table 2). In the initial nanoES-Q-TOF mass spectra, abundant $[\mathrm{M}+\mathrm{K}]^{+}$ions were present in addition to $[\mathrm{M}+\mathrm{Na}]^{+}$ions, complicating the spectra. After addition of a small amount of sodium chloride to the fractions, the intensity of the $[\mathrm{M}+\mathrm{K}]^{+}$ions was reduced significantly and the spectra clearly show differences in relative ion intensities from LCOs produced at $12^{\circ} \mathrm{C}$ (Fig. 3C) and $28^{\circ} \mathrm{C}$ (Fig. 3D). The major LCO structures are produced at both temperatures but yield ions having different relative intensities, while some minor LCO components are only observed at one temperature. Clear differences in the relative ion intensities of the ion at $\mathrm{m} / \mathrm{z}$ $1362.7\left([\mathrm{M}+\mathrm{Na}]^{+}\right.$for the major doubly acetylated LCO structure) due to the difference in growth temperature are observed. In addition, in the spectrum obtained from LCOs produced at $28^{\circ} \mathrm{C}$ this ion was shown by MS/MS to consist of a mixture of the doubly acetylated $\mathrm{LCO} \mathrm{V}\left(\mathrm{C}_{18: 1}, \mathrm{Ac}, \mathrm{Ac}\right)$ and the monoacetylated $\mathrm{LCO} \mathrm{V}\left(\mathrm{C}_{20: 2-\mathrm{OH}}, \mathrm{Ac}\right)$. The difference between the amounts of nodX-mediated, doubly acetylated LCOs produced by strain ANU843 ${ }^{\mathrm{RR}}$.pRI4003 at 12 and $28^{\circ} \mathrm{C}$ is comparable with that observed for strain A1. However, the relative abundance of the ion at $\mathrm{m} / \mathrm{z} 1362.7$ is lower in the spectrum of LCOs produced at $12^{\circ} \mathrm{C}$ by strain ANU843 ${ }^{\mathrm{RR}}$.pRI4003 than in that of those produced by strain A1 (Fig. 3A,B).

Both tetrameric and pentameric LCOs bearing $\mathrm{C}_{18: 1}$ (at $\mathrm{m} / \mathrm{z}$ 1075.6 and 1278.7, respectively) or $\mathrm{C}_{16: 1}$ together with one acetyl substituent (at $\mathrm{m} / \mathrm{z} 1089.6$ and 1292.7 , respectively) are clearly produced at $12^{\circ} \mathrm{C}$, but are barely observable or are absent at $28^{\circ} \mathrm{C}$ (see Figure 3C,D). At the lower temperature, more LCOs bearing fatty acyl chains containing a hydroxyl group are produced, since pseudomolecular ions observed at $m / z \quad 1061.6 \quad\left(\operatorname{IV}\left(\mathrm{C}_{16: 2-\mathrm{OH}}\right)\right), \quad 1063.6 \quad\left(\operatorname{IV}\left(\mathrm{C}_{16: 1-\mathrm{OH}}\right)\right), \quad 1264.7$ $\left(\mathrm{IV}\left(\mathrm{C}_{16: 2-\mathrm{OH}}\right)\right)$, and $1266.7\left(\mathrm{IV}\left(\mathrm{C}_{16: 1-\mathrm{OH}}\right)\right)$ are present at higher relative intensities in the spectrum obtained from LCOs produced at $12^{\circ} \mathrm{C}$ than in that from those produced at $28^{\circ} \mathrm{C}$. Furthermore, the relative amount of $\mathrm{HexNAc}_{3}$ LCOs produced is much higher at $12^{\circ} \mathrm{C}$ than at $28^{\circ} \mathrm{C}$ (cf. nanoES mass spectra from LCOs from strain A1; Fig. 3A,B). LCOs that bear highly unsaturated fatty acids containing up to five double bonds are produced as minor components at both temperatures. The relative amounts do not seem to be influenced significantly by the different growth temperatures. No absorption maxima above $330 \mathrm{~nm}$, corresponding to four double bonds in conjugation with the carbonyl group, are observable in the isograms obtained from LCOs produced at 12 and $28^{\circ} \mathrm{C}$ at the retention times corresponding to the fractions in which the $\mathrm{C}_{20: 5}$ fatty acyl-bearing LCOs are observed, suggesting that not all five double bonds are in conjugation with the carbonyl group.

The FAB and MALDI mass spectra of the pooled HPLC fractions at different dilutions (not shown) are comparable with the nanoES mass spectra, with only some minor differences in relative ion intensities observed.

Figure 4 shows the nanoES tandem mass spectrum of the sodium-cationized species at $\mathrm{m} / z, 1384.7$ corresponding to $\mathrm{V}\left(\mathrm{C}_{20: 4}, \mathrm{Ac}, \mathrm{Ac}\right)$ produced at $28^{\circ} \mathrm{C}$. Although this precursor ion is of very low intensity (see Figure $3 \mathrm{D}$ ), a good quality tandem mass spectrum was obtained. A range of different fragment ions is present, corresponding to A-, B-, C-, Y-, and BYtype ions (nomenclature after Domon and Costello 1988)), allowing the structure to be identified (see fragmentation scheme in Figure 4). The series of $B_{n}$ and $Y_{n}$ ions observed at $m / z$ 512, 715, 918, 1121, and $m / z$ 489, 692, 895, respectively, shows that one acetyl group, that mediated by nodL, is located on the nonreducing-terminal HexNAc residue, while the second acetyl group, that mediated by $\operatorname{nodX}$, is positioned on the reducing-terminal residue. In comparison to the high-energy tandem mass spectra obtained by FAB-MS of protonated precursor ions, $Y_{n}$ ions and double cleavage ions $\left(B_{m} Y_{n}\right)$ are of higher relative abundance in the nanoES spectrum obtained from sodiated species obtained at relatively low collision energies. $[\mathrm{M}+\mathrm{Na}]^{+}$ions corresponding to hydroxylated fatty acyl-containing LCOs are isobaric with $[\mathrm{M}+\mathrm{K}]^{+}$ions corre-

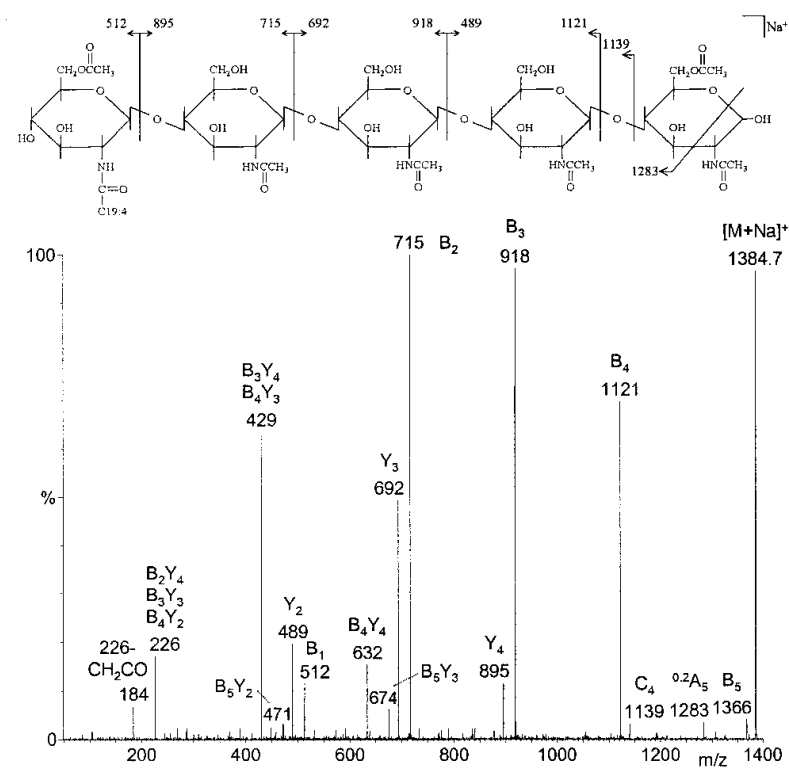

Fig. 4. Nano-electrospray tandem mass spectrum of lipo-chitin oligosaccharide (LCO) component $\mathrm{V}\left(\mathrm{C}_{20: 4}, \mathrm{Ac}, \mathrm{Ac}\right)$ produced at $28^{\circ} \mathrm{C}$ by Rhizobium leguminosarum bv. trifolii ANU843 ${ }^{\mathrm{RR}}$.pRI4003 on collision of $\mathrm{m} / \mathrm{z}$ 1384.7 from the pooled high-performance liquid chromatography (HPLC) fraction. Instrumental settings: capillary voltage $2800 \mathrm{~V}$, cone voltage $140 \mathrm{~V}$, collision energy $70-72 \mathrm{eV}$. The $\mathrm{m} / z$ values are quoted as nominal masses. 
sponding to their nonhydroxylated analogs. $Y_{n}$ and double cleavage ions, however, allow us to distinguish fragments derived from $[\mathrm{M}+\mathrm{Na}]^{+}$and from $[\mathrm{M}+\mathrm{K}]^{+}$precursors and so to determine the identity of the cationizing species and thus to reveal the presence of a mixture of isobaric $[\mathrm{M}+\mathrm{Na}]^{+}$and $[\mathrm{M}+\mathrm{K}]^{+}$precursor ions; e.g., $\mathrm{B}_{3} \mathrm{Y}_{4} / \mathrm{B}_{4} \mathrm{Y}_{3}$ ions originating from sodiated $\mathrm{HexNAc}_{5}$-containing precursor ions are observed at $m / z 429$ (see Figure 4), while the potassium-cationized ana$\operatorname{logs}$ are present at $\mathrm{m} / \mathrm{z} 445$. B ions alone do not allow such distinctions to be made as the $\mathrm{B}$ ion series from an $[\mathrm{M}+\mathrm{Na}]^{+}$ precursor bearing a hydroxylated fatty acid and those from an $[\mathrm{M}+\mathrm{K}]^{+}$precursor bearing a nonhydroxylated fatty acid are isobaric. Using nanoES-MS/MS, we were able to distinguish between many of the isobaric LCO structures present in the pooled fractions obtained from $R$. leguminosarum bv. trifolii ANU843 ${ }^{\mathrm{RR}}$.pRI4003 (see Table 2).

In some tandem mass spectra a mass difference of 249 mass units was observed between the parent ion and the highest mass $\mathrm{B}$ ion corresponding to the reducing HexNAc residue and an additional group with a mass of 28 mass units. Bloemberg et al. (1995) described this additional group present in LCOs from $R$. leguminosarum bv. viciae RBL5900 (pMP2109,pMP2368,pMP3444) as being located on C-1 of the reducing-terminal HexNAc residue and suggested that it probably corresponds to an ethyl glycoside. This sort of glycosidic substitution has also been observed in LCOs from other related microorganisms, e.g., in Bradyrhizobium japonicum glycerol was reported to be glycosidically linked to the reducing-terminal GlcNAc residue (Carlson et al. 1993). We have been able to identify, by CID-MS/MS, five different LCOs containing such an ethyl glycoside (Et), i.e., IV $\left(\mathrm{C}_{18: 1}, \mathrm{Ac}, \mathrm{Et}\right), \mathrm{IV}\left(\mathrm{C}_{18: 0}, \mathrm{Ac}, \mathrm{Et}\right), \mathrm{V}\left(\mathrm{C}_{18: 1}, \mathrm{Ac}, \mathrm{Et}\right)$, and $\mathrm{V}\left(\mathrm{C}_{18: 0} \mathrm{Ac}\right.$, $\mathrm{Et})$ produced at both temperatures, and $\mathrm{IV}\left(\mathrm{C}_{18: 2-\mathrm{OH}}, \mathrm{Ac}, \mathrm{Et}\right)$ produced only at $28^{\circ} \mathrm{C}$ (see Table 2). The ethyl glycosidecontaining LCOs elute later than their analogs lacking this substituent, consistent with the expectation that this group increases the overall hydrophobicity of the LCO molecules. The tandem mass spectrum obtained from the precursor ion at $\mathrm{m} / \mathrm{z}$ 1348.8 (Fig. 5) nicely demonstrates the identification of a mixture of LCOs $\left(\mathrm{V}\left(\mathrm{C}_{18: 1}, \mathrm{Ac}, \mathrm{Et}\right), \mathrm{V}\left(\mathrm{C}_{16: 2-\mathrm{OH}}, \mathrm{Ac}, \mathrm{Ac}\right)\right.$, and $\left.\mathrm{V}\left(\mathrm{C}_{20: 1}, \mathrm{Ac}\right)\right)$ present in the pooled HPLC fraction obtained at $28^{\circ} \mathrm{C}$ that have the same molecular mass but different tandem mass spectra. The $\mathrm{B}_{\mathrm{n}}$ and $\mathrm{Y}_{\mathrm{n}}$ ions observed at $\mathrm{m} / \mathrm{z}$ 490, 693, 896,1099 , and $m / z 272,475,678,881$, respectively, allow the ethyl glycoside-containing $\operatorname{LCO} \mathrm{V}\left(\mathrm{C}_{18: 1}, \mathrm{Ac}, \mathrm{Et}\right)$ to be identified (see fragmentation scheme in Figure 5).

Interestingly, unusual fragment ions of low intensity are observed in tandem mass spectra of LCOs bearing hydroxy fatty acyl chains from both $R$. leguminosarum bv. viciae $\mathrm{A} 1$ and $R$. leguminosarum bv. trifolii ANU843 ${ }^{\mathrm{RR}}$.pRI4003. In the tandem mass spectrum of $\operatorname{IV}\left(\mathrm{C}_{18: 1-\mathrm{OH}}, \mathrm{Ac}\right)$ present in HPLC fraction 4 produced at $12^{\circ} \mathrm{C}$ from strain $\mathrm{A} 1$ at $\mathrm{m} / z 1133.8$ (Fig. 6) these unusual ions are clearly present at $m / z$ 268, 471, 674, and 895 . The latter ion corresponds in mass to a species consisting of four HexNAc residues and one acetyl group, indicating that the fatty acyl chain is cleaved in such a way that an amidebound $\mathrm{C}_{2} \mathrm{H}_{3} \mathrm{O}$ group remains on the nonreducing-terminal residue (loss of 238 mass units from the precursor ion). This kind of fragment ion from amide-linked 3-hydroxy fatty acids was described for the first time in post-source decay spectra of different lipopolysaccharide-derived lipid A structures
(Lindner and Luethje 1998). We propose that the mechanism of this fragmentation corresponds to a McLafferty rearrangement of the fatty acyl chain following cleavage between $\mathrm{C}-2$ and C-3 comparable with that occurring on fragmentation of hydroxy fatty acids under conditions of electron ionization (Murphy 1993). The ions in Figure 6 at $\mathrm{m} / \mathrm{z}, 268,471$, and 674 are the $\mathbf{B}_{1}, \mathbf{B}_{2}$, and $\mathbf{B}_{3}$ analogs of this $\mathbf{B}_{4}$ ion at $m / z$ 895. In theory, these ions could also correspond to $\mathrm{B}_{\mathrm{m}} \mathrm{Y}_{\mathrm{n}}$ ions arising from an LCO bearing an acetyl group on the reducingterminal residue (redAc) instead of the nodL-mediated acetyl group on the nonreducing-terminal residue, but there is no other evidence in the spectrum for the presence of such a nodX-mediated acetyl group on tetrameric LCOs, e.g., a $\mathrm{B}_{3}$ ion at $m / z, 870$ is not observed. The loss of 60 mass units from
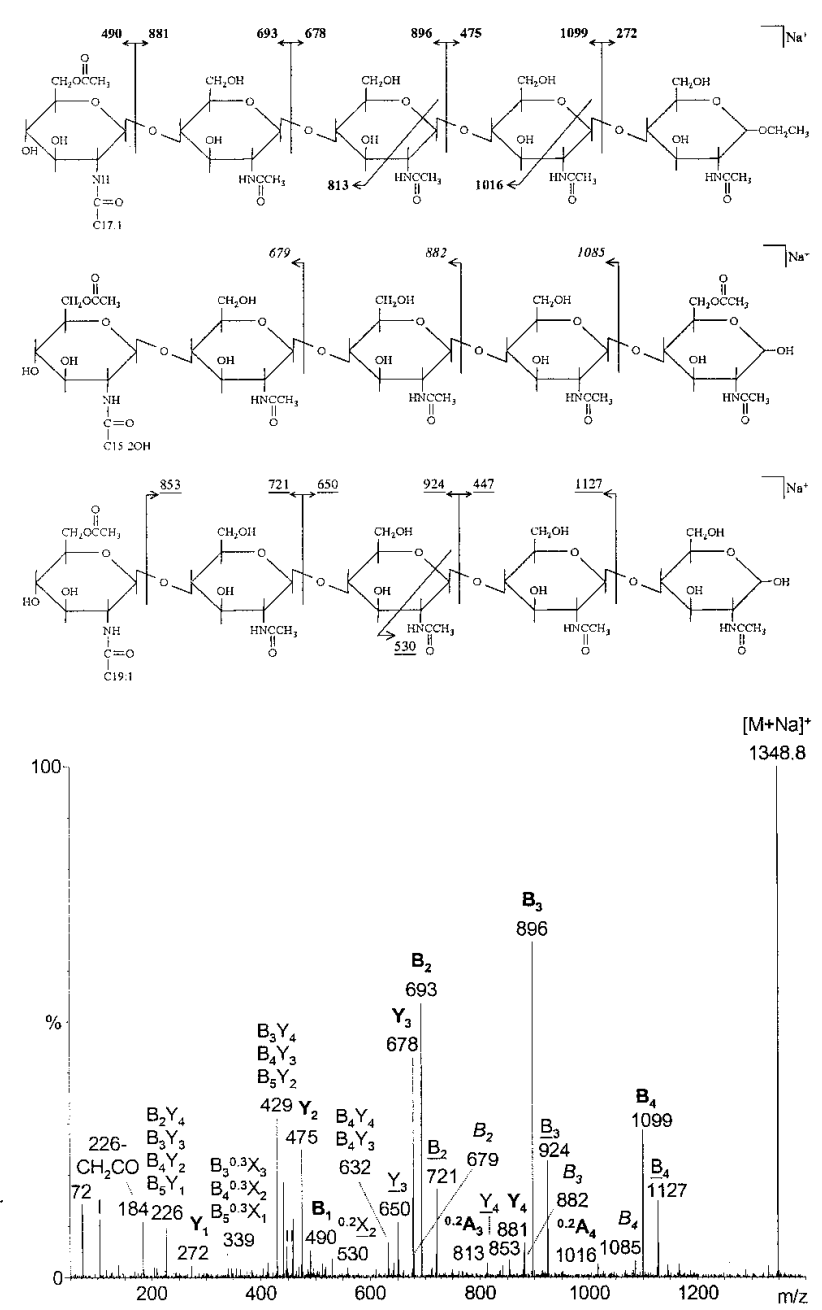

Fig. 5. Nano-electrospray tandem mass spectrum obtained on collision of $\mathrm{m} / \mathrm{z}$ 1348.8, which corresponds to a mixture of lipo-chitin oligosaccharide (LCO) components $\mathrm{V}\left(\mathrm{C}_{18: 1}, \mathrm{Ac}, \mathrm{Et}\right), \mathrm{V}\left(\mathrm{C}_{16: 2-\mathrm{OH}}, \mathrm{Ac}, \mathrm{Ac}\right)$, and $\mathrm{V}\left(\mathrm{C}_{20: 1}, \mathrm{Ac}\right)$ produced at $28^{\circ} \mathrm{C}$ by Rhizobium leguminosarum bv. trifolii ANU843 ${ }^{R R}$.pRI4003. Spectrum obtained from the representative composite high-performance liquid chromatography (HPLC) fraction. Instrumental settings: capillary voltage $2800 \mathrm{~V}$, cone voltage $140 \mathrm{~V}$, collision energy 70-72 eV. The $\mathrm{m} / \mathrm{z}$ values are quoted as nominal masses. Fragment ions originating from $\mathrm{V}\left(\mathrm{C}_{18: 1}, \mathrm{Ac}, \mathrm{Et}\right), \mathrm{V}\left(\mathrm{C}_{16: 2-\mathrm{OH}}, \mathrm{Ac}, \mathrm{Ac}\right)$, and $\mathrm{V}\left(\mathrm{C}_{20: 1}, \mathrm{Ac}\right)$ are in bold, in italics, and underlined, respectively. Peak assignment: I, $\mathrm{m} / \mathrm{z}, 104$ also observed in tandem mass spectra from ions not corresponding to LCOs; II, $m / z 447 \mathrm{Y}_{2}$. 
these unusual ions is observed at $\mathrm{m} / \mathrm{z} 835,614$, and 411 and shows that the O-linked acetyl group is still present and is lost as acetic acid $\left(\mathrm{CH}_{3} \mathrm{COOH}\right)$. The fragment ion at $\mathrm{m} / \mathrm{z} 853$ probably results from the loss of ketene $\left(\mathrm{CH}_{2} \mathrm{CO}, 42\right.$ mass units). Loss of ketene is also observed in the tandem mass spectra of $\mathrm{m} / \mathrm{z}, 1384.7$ and 1348.8 (Figs. 4 and 5) from the amide-bound acetyl group of the $\mathrm{B}_{2} \mathrm{Y}_{4} / \mathrm{B}_{3} \mathrm{Y}_{3} / \mathrm{B}_{4} \mathrm{Y}_{2} /\left(\mathrm{B}_{5} \mathrm{Y}_{1}\right)$ ions (which lack the $O$-acetyl group), resulting in the fragment ion at $m / z, 184$.

\section{DISCUSSION}

In this study, TLC, HPLC, and MS analyses have shown that wild-type $R$. leguminosarum bv. viciae $\mathrm{A} 1$ and $R$. leguminosarum bv. trifolii ANU843 ${ }^{\mathrm{RR}}$.pRI4003 both produce larger relative amounts of $n o d X$-mediated, doubly acetylated LCOs after induction with naringenin at $12^{\circ} \mathrm{C}$ than at $28^{\circ} \mathrm{C}$. The second, $\operatorname{nod} X$-mediated $O$-acetyl group is only transferred to pentameric LCOs, where it is attached to the reducing residue, with the major species being $\mathrm{V}\left(\mathrm{C}_{18: 1}, \mathrm{Ac}, \mathrm{Ac}\right)$. This species is the second most abundant component produced at $12^{\circ} \mathrm{C}$ by strain $\mathrm{A} 1$, while the most abundant component is $\operatorname{IV}\left(\mathrm{C}_{18: 1}, \mathrm{Ac}\right)$. Interestingly, the total amount of LCOs produced was larger at a growth temperature of $12^{\circ} \mathrm{C}$ for strain $\mathrm{A} 1$ and at $28^{\circ} \mathrm{C}$ for strain ANU843 ${ }^{\mathrm{RR}}$.pRI4003 while for both strains nodX shows

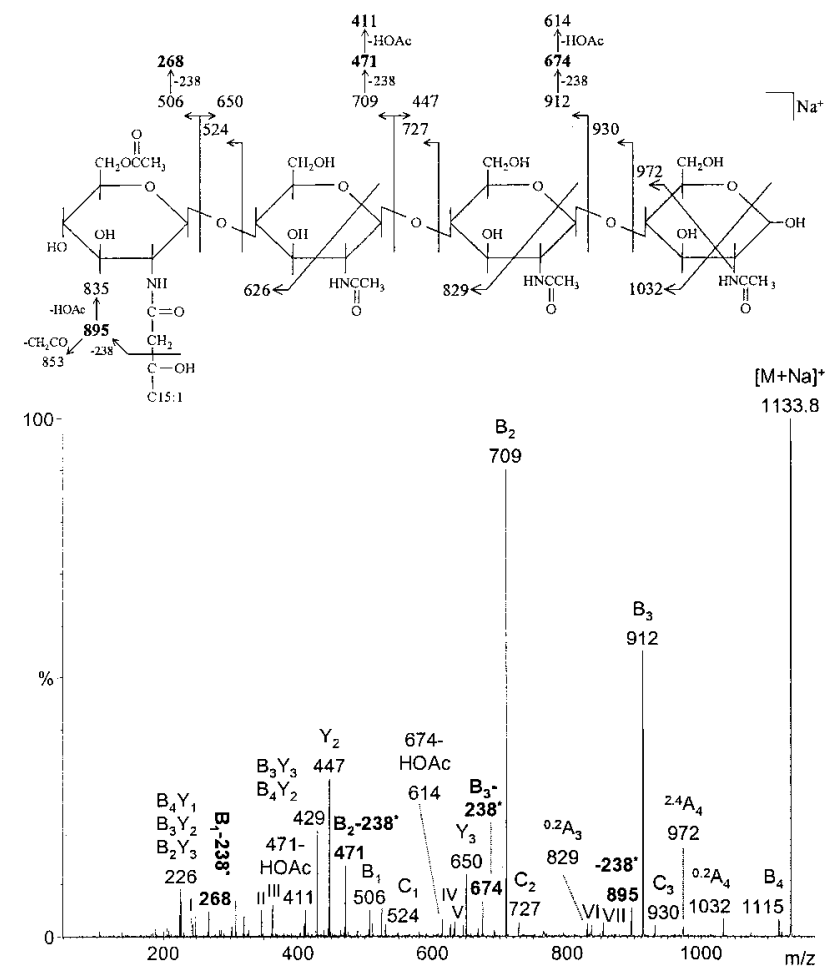

Fig. 6. Nano-electrospray tandem mass spectrum of lipo-chitin oligosaccharide (LCO) component $\mathrm{IV}\left(\mathrm{C}_{18: 1-\mathrm{OH}}, \mathrm{Ac}\right)$ produced at $12^{\circ} \mathrm{C}$ by Rhizobium leguminosarum bv. viciae A1. Spectrum obtained on collision of $\mathrm{m} / z, 1133.8$ from h-performance liquid chromatography (HPLC) fraction 4. Instrumental settings: capillary voltage $1500 \mathrm{~V}$, cone voltage $100 \mathrm{~V}$, collision energy $60 \mathrm{eV}$. The $\mathrm{m} / \mathrm{z}$ values are quoted as nominal masses. *, $\mathrm{C}_{16} \mathrm{H}_{30} \mathrm{O}$ from fatty acyl chain; Peak assignment: I, $\mathrm{m} / \mathrm{z} 242$ $\mathrm{B}_{2} \mathrm{Y}_{3} / \mathrm{B}_{3} \mathrm{Y}_{2} / \mathrm{B}_{4} \mathrm{Y}_{1}$ from [IV $\left.\left(\mathrm{C}_{18: 1}, \mathrm{Ac}\right)+\mathrm{K}\right]^{+} ; \mathrm{II}, \mathrm{m} / z 3460.2 \mathrm{~A}_{4} \mathrm{Y}_{2} ; \mathrm{III}, \mathrm{m} / \mathrm{z}$ $362{ }^{0.2} \mathrm{~A}_{4} \mathrm{Y}_{2}$ from $\left[\mathrm{IV}\left(\mathrm{C}_{18: 1}, \mathrm{Ac}\right)+\mathrm{K}\right]^{+} ; \mathrm{IV}, \mathrm{m} / z 6260.2 \mathrm{~A}_{2} ; \mathrm{V}, \mathrm{m} / z 632$ $\mathrm{B}_{4} \mathrm{Y}_{3}$; VI, $m / z 835$ 895-HOAc; VII, $m / z 853$ 895- $\mathrm{CH}_{2} \mathrm{CO}$. a higher activity at $12^{\circ} \mathrm{C}$. The extra spot in between the two spots corresponding to $\mathrm{GlcNAc}_{4}$ and GlcNAc $\mathrm{LCOs}_{5}$ observed in the TLC profiles at the lower temperatures therefore presumably corresponds to the nodX-mediated, doubly acetylated, pentameric LCOs.

Our results indicate that the activity of the $\operatorname{nodX}$ gene in $R$. leguminosarum bv. viciae $\mathrm{A} 1$ and $R$. leguminosarum bv. trifolii ANU843 ${ }^{\mathrm{RR}}$.pRI4003 is temperature sensitive. This temperature sensitivity could operate at the transcriptional, translational, or post-translational level. Interestingly, resistance genes sym 1 and sym 2 from primitive pea cultivars are active at the lower temperature, blocking nodulation by $R$. leguminosarum bv. viciae lacking nodX. We therefore propose that the gene-for-gene relationship between plant and bacteria has a temperature-sensitive mechanism as an adaptation to environmental conditions.

As the nodX gene is incomplete on pRtRF101, a 14-kb HindIII fragment clone of the ANU843 Sym plasmid that confers very efficient nodulation ability for red or white clover, LCOs containing the nodX-mediated acetyl group were not observed from LPR5045.pRtRF101 (Spaink et al. 1995a). Ovtsyna et al. (1999) therefore reasoned that $\operatorname{nodX}$ is not required for nodulation of these hosts and that any role of $\operatorname{nodX}$ in nodulation of these hosts is therefore probably limited to one influencing the efficiency of nodulation rather than host range. We now suggest that nodX from $R$. leguminosarum bv. trifolii might be involved in the determination of host range on some clover cultivars as it is for R. leguminosarum bv. viciae strains on primitive pea cultivars. If this is the case, then it is possible that such clover cultivars might also possess analogs of the sym 1 and sym2 resistance genes, which would act as an extra selection criterion for improving the efficiency of symbiosis under cold conditions for bacterial strains adapted to low temperatures. It would therefore be interesting to determine whether clover plants bear sym1 or sym 2 analogs or other symbiosis genes having a similar function.

Our results also show additional interesting effects of growth temperature on LCO structures. The major components produced by the two strains are produced at both temperatures but in different relative amounts while some minor species are only produced at one of the two temperatures. At $12^{\circ} \mathrm{C}$, relatively more $\mathrm{GlcNAc}_{3}$ - and $\mathrm{GlcNAc}_{5}$-containing LCOs are produced by both strains. In addition, LCOs bearing hydroxy fatty acyl chains from strain ANU843 ${ }^{\mathrm{RR}}$.pRI4003 are produced more abundantly at $12^{\circ} \mathrm{C}$ than at $28^{\circ} \mathrm{C}$. In addition, the proportion of mono-unsaturated fatty acids, mainly $\mathrm{C}_{16: 1}$ and $\mathrm{C}_{18: 1}$, was relatively larger at $12^{\circ} \mathrm{C}$ consistent with the observation that the growth temperature markedly affects the fatty acid composition of free-living bacteria from $R$. leguminosarum bv. viciae strains $\mathrm{CBh} 5$ and $\mathrm{CBp} 7$ (Théberge et al. 1996); the proportion of unsaturated fatty acids increased significantly when the day/night temperature was lowered from $22 / 15^{\circ} \mathrm{C}$ to $15 / 10^{\circ} \mathrm{C}$. The amount of highly unsaturated fatty acids from strain ANU843 ${ }^{\mathrm{RR}}$.pRI4003, however, does not seem to be influenced significantly by growth temperature in our experiments.

HPLC analysis of the LCOs produced at $12^{\circ} \mathrm{C}$ and $28^{\circ} \mathrm{C}$ by three $R$. leguminosarum strains originating from different climatic regions-Australia (ANU843 ${ }^{\mathrm{RR}}$ ), northwestern Russia (A1), and northern Norway (Tromsø 20-15) — shows how important the environmental condition of growth temperature is 
for LCO yield. In the case of the arctic strain $R$. leguminosarum bv. trifolii Troms $\varnothing 20-15$, it is clear that the lower laboratory growth temperature better reflects the bacterium's normal soil temperature than do the higher growth temperatures tested.

More than 100 different LCO components have been identified from R. leguminosarum bv. trifolii ANU843 ${ }^{\mathrm{RR}}$.pRI4003. These consist of trimeric, tetrameric, and pentameric GlcNAc backbones bearing $\mathrm{C}_{14-22}$ fatty acids that contain zero to five double bonds and sometimes a hydroxyl group, zero to two acetyl substituents and occasionally an ethyl glycoside (see Table 2). Several species are minor components and only observable by nanoES-Q-TOF-MS. Importantly, structural information on these minor components can be obtained with CID-MS/MS because of the high sensitivity of the Q-Tof mass spectrometer in the MS/MS mode. van der Drift et al. (1998) showed that, to obtain CID mass spectra of comparable quality, one-thousandth of the amount of an LCO-containing HPLC fraction from Mesorhizobium loti needed to generate a spectrum with FAB-MS was sufficient to produce a spectrum of better quality with nanoES-Q-TOF-MS. nanoES-Q-TOFMS is thus very well suited for use as an alternative to FABMS for the rapid screening of LCOs. However, the additional information on the presence of a double bond in the fatty acyl chain provided by the observation of a thioglycerol adduct in the FAB mass spectrum is sacrificed. CID-MS/MS of the pooled HPLC fractions is sometimes complicated when a precursor ion consists of both $[\mathrm{M}+\mathrm{Na}]^{+}$and $[\mathrm{M}+\mathrm{K}]^{+}$pseudomolecular ions for different molecular species and/or corresponds to a mixture of LCO structures with the same molecular mass and/or contains ${ }^{13} \mathrm{C}$ isotopes of LCOs slightly lower in mass.

In the course of this study, we noticed that different strains of $R$. leguminosarum bv. trifolii produce LCOs bearing quite different fatty acyl chains; in particular, some strains appear to be much better able to produce the species-specific polyunsaturated fatty acyl chains (Spaink et al. 1995a; van der Drift et al. 1996) than others (Olsthoorn et al. 1997; Orgambide et al. 1995; Philip-Hollingsworth et al. 1995). Since making these observations we have focused a good deal of research effort in our laboratories on determining the reason for this observation. This has resulted in our now being able to identify the mechanism by which production of $R$. leguminosarum bv. trifolii-specific polyunsaturated fatty acylated LCOs is regulated (M. M. A. Olsthoorn, M. Harteveld, H. R. M. Schlaman, J. E. Thomas-Oates, and H. P. Spaink, paper in preparation).

\section{MATERIALS AND METHODS}

\section{Bacterial strains.}

R. leguminosarum bv. trifolii $\mathrm{ANU} 843^{\mathrm{RR}}$ is a spontaneous, rifampicin-resistant derivative of wild-type ANU843 (Djordjevic et al. 1985) that, after inoculation on red clover, was reisolated from nitrogen-fixing nodules. Plasmid pRI4003 contains all the known nod and nif genes from $R$. leguminosarum bv. trifolii ANU843 and is able to restore the ability to induce nitrogen-fixing nodulation on clover to pSym-cured strains (Innes et al. 1988). R. leguminosarum bv. trifolii Troms $\emptyset 20$ 15 , which was isolated from white clover nodules obtained in the arctic zone, was a gift from M. Svenning (Troms $\varnothing$ Univer- sity, Norway). R. leguminosarum bv. viciae A1 is a wild-type strain nodulating Afghan peas and isolated from soils of northwestern Russia (Chetkova and Tikhonovich 1986). $R$. leguminosarum bv. viciae TOM is a wild-type strain nodulating Afghan peas and isolated from Turkish soil (Lie 1978).

\section{Chemical modification.}

Mild base de-esterification of 5\% of HPLC fraction 4 from strain A1 obtained at $12^{\circ} \mathrm{C}$ and $15 \%$ of fraction 3 from strain A1 obtained at $28^{\circ} \mathrm{C}$ was carried out in $200 \mu \mathrm{l}$ of methanol and $200 \mu \mathrm{l}$ of $25 \%$ aqueous ammonia for $18 \mathrm{~h}$ at ambient temperature followed by evaporation to dryness.

\section{TLC analysis.}

Bacteria were grown in $\mathrm{B}^{-}$medium (Spaink et al. 1992) including $1 \mathrm{mM}$ potassium phosphate buffer $\left(\mathrm{pH} \mathrm{7.4)}\right.$ at $28^{\circ} \mathrm{C}$ and $200 \mathrm{rpm}$ (Aqua Shaker; Adolf Kühner, Basel, Switzerland). Spectinomycin $(10 \mu \mathrm{g} / \mathrm{ml})$ was added to the ANU843 ${ }^{\text {RR }}$.pRI4003 culture. The cultures of strains ANU843 ${ }^{\mathrm{RR}}$.pRI4003, A1, and TOM were diluted to an optical density at $620 \mathrm{~nm}\left(\mathrm{OD}_{620}\right)$ of 0.05 , while the ANU843 ${ }^{\mathrm{RR}}$ culture was diluted to an $\mathrm{OD}_{620}$ of 0.09 . LCOs were radiolabeled by growing $3 \mathrm{ml}$ of bacterial cultures overnight in the presence of $0.4 \mu \mathrm{Ci}\left[1-{ }^{14} \mathrm{C}\right]$-D-glucosamine (specific activity 50 $\mathrm{mCi} / \mathrm{mmol}$; Amersham, Buckinghamshire, U.K.) and naringenin $(1 \mu \mathrm{g} / \mathrm{ml})$ as inducer at $6,12,18$, and $28^{\circ} \mathrm{C}$. After addition of $2 \mathrm{ml}$ of water-saturated $n$-butanol and boiling for 10 min, LCOs were isolated from the cultures by extraction. The extracts were dried and redissolved in $30 \mu \mathrm{l}$ of water-saturated $n$-butanol. TLC analyses were carried out with normal phase Silica 60 plates (Aldrich Chemical, Milwaukee, WI) developed with butanol:ethanol:water $(5: 3: 2, \mathrm{vol} / \mathrm{vol} / \mathrm{vol})$. Five microliters of each extract was used for each TLC analysis. The LCOs from $R$. leguminosarum bv. trifolii ANU843 ${ }^{\mathrm{RR}}$.pRI4003, $R$. leguminosarum bv. viciae A1, and $R$. leguminosarum bv. viciae TOM were analyzed on the same plate, while those from $R$. leguminosarum bv. trifolii ANU $843^{R R}$ were analyzed on a separate one. Radioactivity was detected with a phosphor imaging system (Molecular Dynamics, Sunnyvale, CA) and ImageQuant software.

\section{HPLC analysis.}

Bacteria were grown to an $\mathrm{OD}_{620}$ of 0.3 for strain A1 for induction at both 12 and $28^{\circ} \mathrm{C}$, of 1.2 and 1.0 for strain ANU $843^{\mathrm{RR}}$.pRI4003 for induction at 12 and $28^{\circ} \mathrm{C}$, respectively, of 1.0 and 0.8 for strain ANU843 ${ }^{\mathrm{RR}}$ for induction at 12 and $28^{\circ} \mathrm{C}$, respectively, and of 0.72 and 0.73 for strain Troms $\varnothing$ 20-15 for induction at 12 and $28^{\circ} \mathrm{C}$, respectively. Spectinomycin $(10 \mu \mathrm{g} / \mathrm{ml})$ was added to the ANU843 ${ }^{\mathrm{RR}}$.pRI4003 cultures. The cultures were then diluted to 3 liters with $\mathrm{B}^{-}$ medium containing $1 \mu \mathrm{g}$ of naringenin per $\mathrm{ml}$ as inducer and were incubated at 12 or $28^{\circ} \mathrm{C}$ overnight at $100 \mathrm{rpm}$ (Air Cooled Shaker; Marius Instrumenten, Utrecht, NL) for LCO production. LCOs were extracted from the cultures with $n$ butanol (300 ml/liter) and dried. The samples were redissolved in acetonitrile/water $(3: 2, \mathrm{vol} / \mathrm{vol})$ overnight, purified over an octadodecyl silica column (J. T. Baker, Deventer, The Netherlands, $1 \mathrm{mg}$ of sorbent), and subsequently submitted to reverse-phase HPLC on a Pep-S column $(5 \mu \mathrm{m}, 5 \times 250 \mathrm{~mm}$; Pharmacia, Uppsala, Sweden). Elution was performed with a stepwise gradient of mixtures of acetonitrile and water 
(highest grade; J. T. Baker) at a flow of $1 \mathrm{ml} / \mathrm{min}$ and monitored with a Jasco MD-910 photodiode array detector for strains A1 and ANU843 ${ }^{\mathrm{RR}}$.pRI4003 and a Pharmacia RSD2140 photodiode array detector for strains ANU843 ${ }^{\mathrm{RR}}$ and Troms $\varnothing$ 20-15. The gradient used for strain A1 was $20 \%$ acetonitrile for $10 \mathrm{~min}, 30 \%$ for $40 \mathrm{~min}, 40 \%$ for $30 \mathrm{~min}$, and $80 \%$ for $10 \mathrm{~min}$. The gradient used for strain ANU843 ${ }^{\mathrm{RR}}$.pRI4003 was $20 \%$ acetonitrile for $10 \mathrm{~min}, 30 \%$ for $30 \mathrm{~min}, 40 \%$ for $20 \mathrm{~min}, 42 \%$ for $30 \mathrm{~min}, 50 \%$ for $10 \mathrm{~min}$, $60 \%$ for $10 \mathrm{~min}$, and $80 \%$ for $10 \mathrm{~min}$. The gradient used for strains ANU843 ${ }^{\mathrm{RR}}$ and Troms $\varnothing 20-15$ was $30 \%$ acetonitrile for $30 \mathrm{~min}, 40 \%$ for $20 \mathrm{~min}, 42 \%$ for $20 \mathrm{~min}, 50 \%$ for $20 \mathrm{~min}$, $60 \%$ for $10 \mathrm{~min}$, and $80 \%$ for $15 \mathrm{~min}$. HPLC fractions of $1 \mathrm{ml}$ were collected and dried. The resulting HPLC fractions were redissolved in 10 to $1,000 \mu \mathrm{l}$ of dimethyl sulfoxide prior to FAB-MS analysis. To make a more direct comparison of the different LCOs produced at the two temperatures with MS analysis, aliquots from each HPLC fraction were taken so that the volume of the aliquot reflected the number of minutes over which the fraction had been collected and the volume of dimethyl sulfoxide in which it was dissolved. These aliquots were pooled to yield a composite representative fraction for each temperature and strain and the fractions were dried.

MS.

Positive ion mode FAB-MS was carried out with the first two sectors of a Jeol JMS-SX/SX 102A tandem mass spectrometer operated at $10 \mathrm{kV}$ (mass range $\mathrm{m} / z, 200$ to 2000) accelerating voltage. The FAB gun was operated at $4 \mathrm{kV}$ accelerating voltage with an emission current of $10 \mathrm{~mA}$ and xenon as the bombarding gas. Spectra were scanned at a speed of 30 $\mathrm{s}$ for the full mass range specified by the accelerating voltage used and were recorded and processed on a Hewlett-Packard HP 9000 data system with the Jeol Complement software. The probe was loaded with $1 \mu \mathrm{l}$ of sample solution into a matrix of thioglycerol ( 2 to $3 \mu \mathrm{l}$ ). A matrix of 3-nitrobenzyl alcohol was used to generate $[\mathrm{M}+\mathrm{Na}]^{+}$ions.

nanoES-Q-TOF-MS was performed with a Micromass QTof hybrid tandem mass spectrometer equipped with a Z-spray sample introduction system and gold-coated glass capillaries in a nanospray ionization source. The capillary was loaded with 1 to $3 \mu \mathrm{l}$ of an individual or pooled HPLC fraction in acetonitrile:water:formic acid (50:50:0.1, vol/vol/vol) and a potential of +1500 to $2800 \mathrm{~V}$ was applied to it. Sodium chloride $(5 \mathrm{mM})$ was added to the two pooled HPLC fractions from $A N U 843^{\mathrm{RR}}$.pRI4003 to displace potassium. The source temperature was $80^{\circ} \mathrm{C}$. The quadrupole was used in the $R_{\mathrm{f}^{-}}$ only mode. TOF mass spectra were integrated every $2.3 \mathrm{~s}$ over the $\mathrm{m} / \mathrm{z}, 200$ to 2000 range and recorded with a cone voltage varying between 25 and $140 \mathrm{~V}$. The data were recorded and processed with the MassLynx software, version 3.0. Mass calibration was performed by multiple-ion monitoring of the singly charged $[\mathrm{M}+\mathrm{Na}]^{+}$maltooligosaccharide signals derived from corn syrup (Sigma Chemicals, St. Louis, MO). CIDMS/MS was performed with the quadrupole to select the precursor ion for fragmentation in the hexapole collision cell. Argon was used as the collision gas and the collision energy varied between 40 and $80 \mathrm{eV}$. Product ions were analyzed with the orthogonal TOF analyzer.

MALDI-TOF-MS experiments were performed on a PerSeptive Biosystems Voyager-DE STR with a BioSpectrometry
Workstation with PerSeptive GRAMS/386 software. Positive ion mode spectra were recorded in the reflectron mode over the $\mathrm{m} / \mathrm{z} 600 \mathrm{~m}$ to 2000 mass range with an acceleration voltage of $20 \mathrm{kV}$, grid voltages of 15.4 and $14.6 \mathrm{kV}$ for the pooled HPLC fractions from strains A1 and ANU843 ${ }^{\mathrm{RR}}$.pRI4003, respectively, a guide wire voltage of $4 \mathrm{~V}$, and a delay time of 150 ns. 2,5-Dihydroxybenzoic acid was used as the matrix, made up as a saturated solution $(10 \mathrm{mg} / \mathrm{ml})$ in acetonitrile:water $(1: 1, \mathrm{vol} / \mathrm{vol})$ containing $10 \mathrm{mM}$ sodium chloride that was mixed 1:1 (vol/vol) with the pooled HPLC fractions in acetonitrile:water:formic acid (50:50:0.1, vol/vol/vol). The preparations were irradiated at $337 \mathrm{~nm}$ with $3 \mathrm{~ns}$ pulses from a nitrogen laser.

\section{ACKNOWLEDGMENTS}

We are grateful to M. Harteveld for growing $R$. leguminosarum bv. trifolii ANU843 ${ }^{\mathrm{RR}}$.pRI4003 at $12^{\circ} \mathrm{C}$ and extracting and fractionating its LCOs by HPLC. We would also like to thank M. Svenning from the Troms $\emptyset$ University (Norway) for kindly providing the R. leguminosarum bv. trifolii strain Troms $\varnothing 20-15$. The work was supported by the Netherlands Organization for Scientific Research (NWO) with financial aid from the Netherlands Foundation for Chemical Research (SON).

\section{LITERATURE CITED}

Bloemberg, G. V., Kamst, E., Harteveld, M., van der Drift, K. M. G. M., Haverkamp, J., Thomas-Oates, J. E., Lugtenberg, B. J. J., and Spaink, H. P. 1995. A central domain of Rhizobium NodE protein mediates host specificity by determining the hydrophobicity of fatty acyl moieties of nodulation factors. Mol. Microbiol. 16:1123-1136.

Bordeleau, L. M., and Prévost, D. 1994. Nodulation and nitrogen fixation in extreme environments. Plant Soil 161:115-125.

Carlson, R. W., Sanjuan, J., Bhat, U. R., Glushka, J., Spaink, H. P., Wijfjes, A. H. M., Van Brussel, A. A. N., Stokkermans, T. J. W., Peters, N. K., and Stacey, G. 1993. The structures and biological activities of the lipo-oligosaccharide nodulation signals produced by type I and II strains of Bradyrhizobium japonicum. J. Biol. Chem. 268: 18372-18381.

Chetkova, S. A., and Tikhonovich, I. A. 1986. Isolation and analysis of Rhizobium leguminosarum strains which are effective on Afghanistan peas. Microbiologia (in Russian) 55:143-147.

Davis, E. O., Evans, I. J., and Johnston, A. W. B. 1988. Identification of $\operatorname{nodX}$, a gene that allows $R$. leguminosarum bv. viciae strain TOM to nodulate Afghanistan peas. Mol. Gen. Genet. 212:531-535.

Djordjevic, M. A., Schofield, P. R., and Rolfe, B. G. 1985. Tn5 mutagenesis of Rhizobium trifolii host-specific nodulation genes result in mutants with altered host-range ability. Mol. Gen. Genet. 200: 463-471.

Domon, B., and Costello, C. E. 1988. A systematic nomenclature for carbohydrate fragmentations in FAB-MS/MS spectra of glycoconjugates. Glycoconjugate J. 5:397-409.

Downie, J. A. 1989. The nodL gene from Rhizobium leguminosarum is homologous to the acetyl transferases encoded by $l a c A$ and $c y s E$. Mol. Microbiol. 3:1649-1651.

Ek-Jandér, J., and Fåhraeus, G. 1971. Adaptation of Rhizobium to subarctic environment in Scandinavia. Plant Soil (special vol.) pp. 129-137.

Firmin, J. L., Wilson, K. E., Carlson, R. W., Davies, A. E., and Downie, J. A. 1993. Resistance to nodulation of cv. Afghanistan peas is overcome by nodX, which mediates an O-acetylation of the Rhizobium leguminosarum lipo-oligosaccharide nodulation factor. Mol. Microbiol. 10:351-360.

Fukuda, M. N., Dell, A., Oates, J. E., Wu, P., Klock, J. C., and Fukuda, M. 1985. Structures of glycosphingolipids isolated from human granulocytes. J. Biol. Chem. 260:1067-1082.

Geurts, R. 1998. A genetic approach to study rhizobial Nod factor and mycorrhizal fungi activated signaling. Ph.D. thesis. Wageningen Agricultural University, Wageningen, The Netherlands.

Geurts, R., Heidstra, R., Hadri, A.-E., Downie, J. A., Franssen, H., Van Kammen, A., and Bisseling, T. 1997. Sym2 of pea is involved in a 
nodulation factor-perception mechanism that controls the infection process in the epidermis. Plant Physiol. 115:351-359.

Gibson, A. H. 1968. Nodulation failure in Trifolium subterraneum L. cv. Woogenellup (syn. Marra). Aust. J. Agric. Res. 19:907-918.

Gibson, A. H. 1971. Factors in the physical and biological environment affecting nodulation and nitrogen fixation by legumes. Plant Soil (special vol.) pp. 139-152.

Innes, R. W., Hirose, M. A., and Kuempel, P. L. 1988. Induction of nitrogen-fixing nodules on clover requires only 32 kilobase pairs of DNA from Rhizobium trifolii symbiosis plasmid. J. Bacteriol. 170: 3793-3802.

Kozik, A., Heidstra, R., Horvath, B., Kulikova, O., Tikhonovich, I., Ellis, T. H. N., Van Kammen, A., Lie, T. A., and Bisseling, T. 1995. Pea lines carrying sym 1 or sym 2 can be nodulated by Rhizobium strains containing nodX; sym1 and sym2 are allelic. Plant Sci. 108:41-49.

Lewis-Henderson, W. R., and Djordjevic, M. A. 1991a. A cultivarspecific interaction between Rhizobium leguminosarum bv. trifolii and subterranean clover is conditioned by nodM, other bacterial cultivar specificity genes, and a single recessive host gene. J. Bacteriol. 173: 2791-2799.

Lewis-Henderson, W. R., and Djordjevic, M. A. 1991b. NodT, a positively-acting cultivar specificity determinant controlling nodulation of Trifolium subterranean by Rhizobium leguminosarum bv. trifolii. Plant Mol. Biol. 16:515-526.

Lie, T. A. 1978. Symbiotic specialization in pea plants: The requirement of specific Rhizobium strains for peas from Afghanistan. Ann. Appl. Biol. 88:462-465.

Lie, T. A. 1984. Host genes in Pisum sativum L. conferring resistance to European Rhizobium leguminosarum strains. Plant Soil 82:415-425.

Lindner, B., and Luethje, H. 1998. PSD-MALDI-MS of lipid A: a tool for the fatty acid analysis. Poster C03 WEPO 064 in: Advances in Mass Spectrometry. (CD ROM) E. J. Karjalainen, A. E. Hesso, J. E. Jalonen, and U. P. Karjalainen, eds. Elsevier Science Publishers, Amsterdam.

McKay, I. A., and Djordjevic, A. 1993. Production of Nod metabolites by Rhizobium leguminosarum bv. trifolii are disrupted by the same environmental factors that reduce nodulation in the field. Appl. Environ. Microbiol. 59:3385-3392.

Murphy, R. C. 1993. Mass Spectrometry of Lipids. 1st ed. Plenum Press, New York.

Olsthoorn, M., Haverkamp, J., Thomas-Oates, J., and Spaink, H. 1997. Rhizobial lipo-chitin oligosaccharide structures are growthtemperature dependent: A mass spectrometric study. Poster IP10. Informal Meeting on Mass Spectrometry, 15th.

Orgambide, G. G., Lee, J., Hollingsworth, R. I., and Dazzo, F. B. 1995. Structurally diverse chitooligosaccharide Nod factors accumulate primarily in membranes of wild type Rhizobium leguminosarum bv. trifolii. Biochemistry 34:3832-3840.

Ovtsyna, A. O., Rademaker, G.-J., Esser, E., Weinman, J., Rolfe, B. G., Tikhonovich, I. A., Lugtenberg, B. J. J., Thomas-Oates, J. E., and
Spaink, H. P. 1999. Comparison of characteristics of the nodX genes from various Rhizobium leguminosarum strains. Mol. Plant-Microbe Interact. 12:252-258

Philip-Hollingsworth, S., Orgambide, G. G., Bradford, J. J., Smith, D. K., Hollingsworth, R. I., and Dazzo, F. B. 1995. Mutation or increased copy number of nodE has no effect on the spectrum of chitooligosaccharide Nod factors made by Rhizobium leguminosarum bv. trifolii. J. Biol. Chem. 270:20968-20977.

Richardson, A. E., Simpson, R. J., Djordjevic, M. A., and Rolfe, B. G. 1988. Expression of nodulation genes in Rhizobium leguminosarum bv. trifolii is affected by low $\mathrm{pH}$ and by $\mathrm{Ca}$ and $\mathrm{Al}$ ions. Appl. Environ. Microbiol. 54:2541-2548.

Sadowsky, M. J., and Graham, P. H. 1998. Pages 155-172 in: The Rhizobiaceae, molecular biology of model plant-associated bacteria. H. P. Spaink, A. Kondorosi, and P. J. J. Hooykaas, eds. Kluwer Academic Publishers, Dordrecht, The Netherlands.

Spaink, H. P. 1992. Rhizobial lipo-oligosaccharides: Answers and questions. Plant Mol. Biol. 20:977-986.

Spaink, H. P., Aarts, A., Stacey, G., Bloemberg, G. V., Lugtenberg, B. J. J., and Kennedy, E. P. 1992. Detection and separation of Rhizobium and Bradyrhizobium Nod metabolites using thin-layer chromatography. Mol. Plant-Microbe Interact. 5:72-80.

Spaink, H. P., Bloemberg, G. V., van Brussel, A. A. N., Lugtenberg, B. J. J., van der Drift, K. M. G. M., Haverkamp, J., and Thomas-Oates, J. E. 1995a. Host specificity of Rhizobium leguminosarum is determined by the hydrophobicity of highly unsaturated fatty acyl moieties of the nodulation factors. Mol. Plant-Microbe Interact. 8:155-164.

Spaink, H. P., Sheeley, D. M., Van Brussel, A. A. N., Glushka, J., York, W. S., Tak, T., Geiger, O., Kennedy, E. P., Reinhold, V. N., and Lugtenberg, B. J. J. 1991. A novel highly unsaturated fatty acid moiety of lipo-oligosaccharide signals determines host specificity of Rhizobium. Nature 354:125-130.

Spaink, H. P., Wijfjes, A. H. M., and Lugtenburg, B. J. J. 1995b. Rhizobium NodI and NodJ proteins play a role in the efficiency of secretion of lipo-chitin oligosaccharides. J. Bacteriol. 177:6276-6281.

Théberge, M.-C., Prévost, D., and Chalifour, F.-P. 1996. The effect of different temperatures on the fatty acid composition of Rhizobium leguminosarum bv. viciae in the faba bean symbiosis. New Phytol. 134: 657-664.

Trotman, A. P., and Weaver, R. W. 1995. Tolerance of clover rhizobia to heat and desiccation stresses in soil. Soil Sci. Soc. Am. J. 59:466-470. van der Drift, K. M. G. M., Olsthoorn, M. M. A., Brüll, L. P., Blok-Tip, L., and Thomas-Oates, J. E. 1998. Mass spectrometric analysis of lipo-chitin oligosaccharides - signal molecules in the host-specific legume-rhizobium symbiosis. Mass Spectrom. Rev. 17:75-95.

van der Drift, K. M. G. M., Spaink, H. P., Bloemberg, G. V., Van Brussel, A. A. N., Lugtenberg, B. J. J., Haverkamp, J., and Thomas-Oates, J. E. 1996. Rhizobium leguminosarum bv. trifolii produces lipo-chitin oligosaccharides with nodE dependent highly unsaturated fatty acyl moieties. J. Biol. Chem. 271:22563-22569. 